\title{
Instrumentalne wykorzystywanie władzy sędziowskiej po wyroku TSUE - wieloaspektowa analiza legalnej korupcji
}

\section{Wprowadzenie}

Problematyka dotycząca zmian w polskim sądownictwie na przestrzeni kilku ostatnich lat jest zagadnieniem niezwykle często pojawiającym się w debacie publicznej. Do społeczeństwa za pośrednictwem różnych mediów (prywatnych i publicznych) trafia przekaz informacyjny, który ma edukować obywateli, kształtować ich świadomość i sposób myślenia, a także wpływać na percepcję oraz ocenę podawanych faktów, decyzji i procesów. W ostatnich miesiącach, za sprawą wyroku Trybunału Sprawiedliwości Unii Europejskiej (TSUE) z 19 listopada 2019 r. i kolejnych działań podejmowanych przez środowisko sędziowskie, ponownie dochodzi do ożywionych sporów i narastających konfliktów wokół tzw. reformy wymiaru sprawiedliwości, które odbijają się szerokim echem w polityce krajowej i na arenie międzynarodowej. Daje się przy tym zauważyć odmienność prezentowanych opinii oraz komentarzy na temat tych samych zdarzeń, a ponadto jawny subiektywizm poglądów wyrażanych przez wąskie grono starannie wyselekcjonowanych i uprzywilejowanych osób, za sprawą przyznanego im prawa do występowania $\mathrm{w}$ mediach - dzielenia się swoją wiedzą z opinią publiczną.

Konsekwencją takiego stanu rzeczy jest to, że znaczna część informacji kierowanych do odbiorców nie ma obiektywnego charakteru. Co więcej, dość często są biegunowo dalekie od rzetelnych i bezstronnych

* Waldemar Walczak, dr, Uniwersytet Łódzki, e-mail: waldek.lodz@wp.pl, https:// orcid.org/0000-0003-4841-9364. 
rozważań, ponieważ w publicznej dyskusji poświęconej reformie wymiaru sprawiedliwości dominują wypowiedzi głoszone przez wybranych przedstawicieli bezpośrednio zainteresowanych stron, brakuje natomiast krytycznych i niezależnych analiz, które nie są pisane na zamówienie i za wynagrodzeniem. Biorąc pod uwagę powyższe, w świetle zaprezentowanych przesłanek wyłania się uzasadnienie dla podjętego problemu badawczego, a jest nim ranga opisywanego problemu i doniosłe znaczenie wymiaru sprawiedliwości w demokratycznym państwie. Dodatkowym argumentem jest to, że każdy polski obywatel ma prawo do wyrażania własnych wniosków, ocen, autonomicznych spostrzeżeń oraz przemyśleń, będących pochodną wnikliwej analizy procesów i zdarzeń występujących w rzeczywistości. Wynika to wprost z przepisu art. 54 ust. 1 Konstytucji Rzeczypospolitej ${ }^{1}$ : „Każdemu zapewnia się wolność wyrażania swoich poglądów oraz pozyskiwania i rozpowszechniania informacji", a art. 73 ustawy zasadniczej ma stanowić gwarancję wolności prowadzenia badań naukowych i ogłaszania ich wyników.

Celem artykułu ${ }^{2}$ jest przedstawienie pragmatycznych, a zarazem krytycznych analiz, które przybliżają do rozpoznania metodyki postępowania w ramach procesów intencjonalnego wykorzystywania władzy sędziowskiej dla określonych celów i potrzeb. Nakreślone zagadnienie problemowe wymusza integrowanie teoretycznych analiz prawnych odnośnie do obowiązujących przepisów z wiedzą empiryczną bazującą na stosowaniu prawa w konkretnych działaniach, tj. procesach podejmowania decyzji w praktyce zarządzania organizacjami. Podstawą formułowanych wniosków oraz własnych ocen są wszechstronne eksploracje konkretnych zdarzeń mających potwierdzenie w rzeczywistości organizacyjnej. Omawiając docierające do opinii publicznej informacje, przyjęto perspektywę myślenia w ujęciu przyczynowo-skutkowym.

Problem badawczy dotyczy prawidłowego zrozumienia, a także właściwej percepcji zasad funkcjonowania systemu ze względu na interpretowanie prawa przez organy wymiaru sprawiedliwości. Zagadnienia poruszane w tekście odnoszą się do następujących tematów:

- wyrok TSUE z 19 listopada 2019 r. jest wieloznacznie i dowolnie interpretowany, co w konsekwencji prowadzi do odmiennych poglądów i wniosków: w ocenie rządu staje się argumentem instrumentalnie

${ }^{1}$ Konstytucja Rzeczypospolitej Polskiej z dnia 2 IV 1997 r. (Dz.U. Nr 78, poz. 483 ze zm.), dalej „Konstytucja RP” lub „Konstytucja”.

${ }^{2}$ Od Redakcji: wszelkie wyróżnienia (także w obrębie cytatów) pochodzą od autora artykułu. 
wykorzystywanym przez niektórych sędziów w celu destabilizacji systemu prawnego, czemu należy się skutecznie przeciwstawić i zapobiec anarchii, zdaniem przedstawicieli środowiska sędziowskiego natomiast daje podstawę do podważenia wprowadzonych reform polskiego sądownictwa;

- wszystkie decyzje podejmowane przez reprezentantów władzy sędziowskiej mające istotny wpływ na funkcjonowanie instytucji wymiaru sprawiedliwości, winny być postrzegane i rozpatrywane w szerszym kontekście sytuacyjnym, gdyż podawane do publicznej wiadomości przesłanki i motywy działań nie zawsze stanowią prawdziwe odzwierciedlenie rzeczywistych intencji, a także celów realizowanych przedsięwzięć;

- te same konstytucyjne zasady, normy i gwarancje, które podawane są jako uzasadnienie dla decyzji stosowania prawa w ramach podejmowanych rozstrzygnięć, w poszczególnych przypadkach mogą być wykorzystywane przez sądy w sposób wybiórczy i selektywny, a jednocześnie pomijane $w$ innych sytuacjach;

- polityka kadrowa, zwłaszcza zaś zasady doboru kadr sędziowskich, a także obsada kierowniczych stanowisk, stanowią najważniejszy aspekt oraz główny wymiar przeprowadzanych zmian w polskim sądownictwie, co oznacza, że meritum toczonych dyskusji i sporów de facto sprowadza się do walki o wpływy i kontrolę nad systemem władzy sądowniczej.

\section{1. "Legalna korupcja" jako wykorzystywanie prawa, posiadanej władzy i pozycji zawodowej}

Szeroko pojmowana korupcja jest zjawiskiem, które daje się zaobserwować we wszystkich sferach funkcjonowania gospodarki, co sprawia, że nakreślony problem może być rozpatrywany w odniesieniu do oceny poczynań piastunów władzy w każdej kategorii organizacji. Analizowane zagadnienie obejmuje swoim zakresem nie tylko przestępstwa korupcyjne, ale również pozostałe formy tzw. legalnej korupcji ${ }^{3}$. Właściwe postrzeganie istoty korupcji, jej odmian, oraz celów przyświecających korupcyjnym praktykom, jest elementem nieodzownym dla

${ }^{3}$ W. Walczak, Korupcja jako sieć wpływów, powiązań i zależności, „Przegląd Bezpieczeństwa Wewnętrznego" 2018, nr 19, s. 11-41; W. Walczak, Legalna korupcja metodą zapewniania korzyści majątkowych i osobistych, "Annales Universitatis Paedagogicae Cracoviensis. Studia de Securitate" 2020, nr 1, s. 217-256. 
poprawnego zrozumienia wielu zdarzeń i procesów, jakie występują we współczesnych realiach. Okazuje się, że decyzje i działania będące jawną egzemplifikacją legalnej korupcji wzbudzają najwięcej kontrowersji, ujawniają wiele zróżnicowanych poglądów, odmiennych opinii i ocen ze względu na to, że niektóre osoby próbują polemizować z faktem, iż takie czyny także zalicza się do kategorii praktyk korupcyjnych.

Syntetyczny i rzeczowy opis pojęcia zawiera się w zdaniu, że legalna korupcja ${ }^{4}$ polega na instrumentalnym wykorzystywaniu prawa, posiadanej władzy i pozycji zawodowej dla partykularnych interesów, oczywiście pod pozorem realizacji innych szczytnych celów, np. usprawnienia funkcjonowania systemu, poprawy efektywności danej organizacji, dbania o dobro wspólne, interes publiczny, praworządność, prawa obywateli itd. Swoim zakresem obejmuje niezwykle obszerny i wieloaspektowy katalog różnorodnych działań oraz decyzji, dla których jedynym i wystarczającym uzasadnieniem jest to, że są one podejmowane przez upoważnione osoby, kolegialne gremia, w ramach posiadanych/ przyznanych uprawnień, na podstawie obowiązujących przepisów prawa. Nie można jednakże tracić z pola widzenia zasadniczego aspektu, legalna korupcja w swojej istocie stanowi bowiem realizację uprzednio starannie zaplanowanych scenariuszy działań, które są niezwykle wyrafinowane i wyjątkowo skuteczne, ponieważ bazując na legitymizacji dla określonych decyzji i czynności prawnych, służą zapewnieniu korzyści wybranym osobom trzecim, a jednocześnie interesom decydenta. Są to działania umyślne, podejmowane z zamiarem bezpośrednim i kierunkowym - nie ma tu mowy o jakichkolwiek przypadkach.

Trzeba pamiętać, że udział w tych przedsięwzięciach biorą zorganizowane grupy starannie dobranych osób, określanych mianem tzw. układów zamkniętych ${ }^{5}$. Funkcjonujące w ramach tak ukształtowanej struktury jednostki łączą wzajemne relacje oraz silne więzi, co sprawia,

${ }^{4}$ G.G. Maciel, L. de Sousa, Legal Corruption and Dissatisfaction with Democracy in the European Union, "Social Indicators Research" 2018, vol. 140, iss. 2, s. 653-674; J. Kusiak, Rule of Law and Rules-Lawyering: Legal Corruption and "Reprivatization Business" in Warsaw, „International Journal of Urban and Regional Research" 2019, vol. 43, iss. 3, s. 589-596; M. Fazekas, I.J. Toth, From Corruption to State Capture: A New Analytical Framework with Empirical Applications from Hungary, "Political Research Quarterly" 2016, vol. 69, iss. 2, s. 320-334; A. Pethe, V. Tandel, S. Gandhi, Unravelling the Anatomy of Legal Corruption: Focusing on 'Honest Graft' by Politicians, „Economic and Political Weekly" 2012, vol. 47, no. 21 , s. 55-62.

${ }^{5}$ W. Walczak, Korupcja - ujęcie prakseologiczne i ekonomiczne, „Policja. Kwartalnik Kadry Kierowniczej Policji" 2019, nr 2, s. 10-21. 
że dla prywatnych interesów działają wspólnie i w porozumieniu. K. Kiciński zaznacza, że "w państwach, w których nie istnieją lub są słabe demokratyczne mechanizmy kontroli władzy, jej przedstawiciele niekoniecznie muszą łamać prawo, by uzyskiwać korzyści wyraźnie wykraczające poza to, co jest społecznie akceptowalne. Mogą, ponieważ sami prawo w sposób arbitralny stanowiąc, są w stanie formułować je tak, by służyło przede wszystkim ich własnym interesom" ${ }^{\prime 6}$. Zgadzając się z tymi poglądami, wypada jednocześnie dostrzec, że demokratycznej kontroli i weryfikacji przez obywateli poddawane są poczynania oraz decyzje podejmowane przez przedstawicieli władzy ustawodawczej i wykonawczej. Z kolei działania reprezentantów władzy sądowniczej pozostają poza jakąkolwiek społeczną kontrola, a dodatkowo na mocy art. 180 ust. 1 Konstytucji RP sędziowie są nieusuwalni. W ustawie zasadniczej przewidziano tylko jedno odstępstwo od tej gwarancji, a mianowicie złożenie sędziego z urzędu może nastąpić "na mocy orzeczenia sądu i tylko w przypadkach określonych w ustawie" (art. 180 ust. 2), dlatego też regulacje ustawowe w przedmiotowym zakresie mają fundamentalne znaczenie.

K. Patora stwierdza, że do obszarów szczególnie zagrożonych korupcją zalicza się m.in. „zatrudnienie w sferze stanowisk państwowych oraz samorządowych", a także "wymiar sprawiedliwości i porządku publicznego w zakresie decyzji procesowych, zaniechania czynności zawodowych"7. Są to trafnie przemyślane, logicznie poprawne i ze wszech miar uzasadnione oceny, które autorka formułuje odnośnie do najbardziej rozpowszechnionych form korupcji. W uzupełnieniu swojej wypowiedzi zaznacza jednocześnie, że polskie prawo karne nie

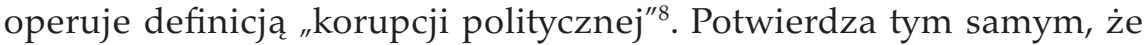
takie procesy, zachowania i decyzje należy określać mianem czynów/ działań będących przejawem legalnej korupcji. Warto w tym miejscu wyjaśnić, że korupcja i nadużycia władzy stwarzają realne zagrożenie nie tylko dla bezpieczeństwa wewnętrznego państwa, ale również są szkodliwe dla zwykłych obywateli we wszystkich sferach życia społecznego9.

${ }^{6} \mathrm{~K}$. Kiciński, „Sygnalista” w państwie prawa - spojrzenie z perspektywy socjologii moralności, w: Skarżypyty, donosiciele, sygnaliści? Studium socjologiczno-prawne, pod red. J. Arcimowicz, M. Bieńko, B. Łaciak, Warszawa 2018, s. 242.

${ }^{7}$ K. Patora, Analiza korupcji, „Studia Iuridica Toruniensia” 2018, nr 22, s. 267.

${ }^{8}$ Ibidem.

${ }^{9}$ N. Duraj, Przestępstwa nadużycia władzy i korupcji w prawie karnym Federacji Rosyjskiej, „Przegląd Policyjny” 2019, nr 2, s. 56. 
W literaturze przedmiotu prezentowane są rozmaite poglądy na temat systemu demokracji konstytucyjnej i roli władzy sądowniczej. Zdaniem R. Piotrowskiego „istotą władzy demokratycznej ustanowionej w Konstytucji RP jest ograniczenie tej władzy po to, by chronić prawa jednostki przed zagrożeniami, jakie może stworzyć panowanie większości, zwłaszcza wtedy, kiedy dąży ona do narzucenia innym swoich wartości i przekonań"10. W takim ujęciu władza sądownicza ma sprawować kontrolę nad poczynaniami władzy demokratycznej, które mogą stwarzać realne niebezpieczeństwo z punktu widzenia praw obywateli. W poprzednim ustroju obowiązującym w Polsce przed 1989 r. społeczeństwo nie było w stanie rozliczać działalności rządzącej partii i weryfikować jej wpływu na obszary funkcjonalne państwa. Jak podkreśla D. Maksimiuk, „PZPR, pełniąc kierowniczą rolę w państwie, była zarazem partią o charakterze państwowym, ingerując w struktury i mechanizmy działania państwa zarówno w sposób bezpośredni, jak i pośredni (uwarunkowania kadrowe, wpływ na stanowienie i egzekucję prawa). W odniesieniu do wymiaru sprawiedliwości czyniła to, wykorzystując narzędzie, jakim była nomenklatura"11.

Nieco inne spojrzenie na misję służby sędziowskiej przedstawia A. Tomza, która odwołuje się do kwestii politycznych nominacji sędziów do Sądu Najwyższego Stanów Zjednoczonych. Według autorki "prawidłowo wybrana trzecia władza musi dążyć do realizacji preferencji społecznych. Zarówno bowiem ta władza, podobnie jak pozostałe, została wybrana w zgodzie $z$ wolą suwerena" ${ }^{12}$. Oznacza to, że "sędzia afirmuje przyjęty w Stanach Zjednoczonych system demokracji konstytucyjnej jako ten, który najmocniej urzeczywistnia i realizuje wolę suwerennego narodu"13. Przenosząc te rozważania na polski grunt, pojawiają się w tym przedmiocie opinie, że oczekiwania społeczne i wola suwerena stanowią legitymizację dla poczynań władzy ustawodawczej i wykonawczej w zakresie przeprowadzanych reform wymiaru sprawiedliwości

${ }^{10}$ R. Piotrowski, Sędziowie i granice władzy demokratycznej w świetle Konstytucji RP, "Ruch Prawniczy, Ekonomiczny i Socjologiczny" 2018, nr 1, s. 215.

${ }^{11}$ D. Maksimiuk, Z działalności Komisji KC PZPR do spraw Wymiaru Sprawiedliwości, Bezpieczeństwa i Porzadku Publicznego w 1957 r. Przyczynek do badań nad wpływem PZPR na wymiar sprawiedliwości, „Miscellanea Historico-Iuridica” 2015, t. 14: Studia dedykowane Profesorowi Adamowi Lityńskiemu w 75-lecie urodzin i 50-lecie pracy naukowej, pod red. P. Fiedorczyka, s. 69.

${ }^{12}$ A. Tomza, Kwestia politycznych nominacji sędziów do Sądu Najwyższego Stanów Zjednoczonych w pogląach Antonina G. Scalii - In memoriam, „Folia Iuridica Universitatis Wratislaviensis" 2018, vol. 7, no. 1, s. 164.

${ }^{13}$ Ibidem. 
w Polsce. Podaje się przy tym argumenty odwołujące się wprost do przepisów Konstytucji, tj. art. 4 ust. 1: „Władza zwierzchnia w Rzeczypospolitej należy do Narodu”, art. 4 ust. 2: „Naród sprawuje władzę przez swoich przedstawicieli lub bezpośrednio". Nie da się zaprzeczyć temu, że to polscy obywatele bioraccy udział w wyborach decydują o tym, kto $\mathrm{w}$ ich imieniu sprawuje rządy $\mathrm{w}$ kraju.

\section{Decyzje kadrowe w świetle prawa do sądu wynikającego $z$ art. 45 Konstytucji RP - sędziowie na tle innych obywateli}

W pierwszej kolejności trzeba wytłumaczyć, że prawo do sądu, wynikające zarówno z art. 45 ust. 1: „Każdy ma prawo do sprawiedliwego i jawnego rozpatrzenia sprawy bez nieuzasadnionej zwłoki przez właściwy, niezależny, bezstronny i niezawisły sąd", a także z art. 6 ust. 1 Konwencji o ochronie praw człowieka i podstawowych wolności: „Każdy ma prawo do sprawiedliwego i publicznego rozpatrzenia jego sprawy w rozsądnym terminie przez niezawisły i bezstronny sąd ustanowiony ustawa przy rozstrzyganiu o jego prawach i obowiązkach o charakterze cywilnym albo o zasadności każdego oskarżenia w wytoczonej przeciwko niemu sprawie karnej", ma swoje dwa podstawowe aspekty:

- prawo do drogi sądowej ( $\mathrm{tj}$. prawo dostępu do sądu oraz uprawnienie do inicjowania w tym celu postępowania przed sądem), co w teorii może być rozumiane tak, że każdy obywatel ma prawo do tego, aby ważne dla niego sprawy o charakterze cywilnym bądź karnym, a także decyzje władz administracyjnych, mogły być rozstrzygnięte przez sąd. Innymi słowy, oznacza to prawo do tego, aby ostateczne sprawiedliwe orzeczenie w sprawie danego obywatela zostało wydane przez właściwy sąd;

- prawo do sprawiedliwego rozpatrzenia sprawy przez niezależny, bezstronny i niezawisły sąd, a zatem organ, który spełnia takie kryteria, a niezależność i bezstronność leżą u podstaw podejmowanych decyzji.

Przedmiotowe zagadnienie rozpatrywane jest z punktu widzenia zasad konstytucyjnych (jako dyrektywa tworzenia prawa ${ }^{14}$ ), prawa do rzetelnego postępowania przed sądem ${ }^{15}$, ale przede wszystkim winno

${ }^{14}$ M. Siudowski, Prawo do sadu. Raport $z$ monitoringu ochrony praw podstawowych w Polsce, Lublin 2006, s. 7.

${ }^{15}$ S. Pilipiec, Zasada prawa do sądu w Konstytucji Rzeczypospolitej Polskiej i Konstytucji Federacji Rosyjskiej, „Annales Universitatis Mariae Curie Skłodowska, Lublin - Polonia”, Sectio G, 2003/2004, vol. 50/51, s. 153. 
być postrzegane w kategorii prawa podmiotowego o zasadniczym znaczeniu $^{16}$, które przysługuje każdemu obywatelowi. Omawiane prawo do sądu - zgodnie z orzecznictwem Trybunału Konstytucyjnego (TK) (wyrok z 13 stycznia 2015 r., sygn. SK 34/12) - „jest jednym z podstawowych praw podmiotowych jednostki i jedną z fundamentalnych zasad praworządności w demokratycznym państwie". Według G. Zalizowskiego prawo to "jest podstawą roszczenia, które przysługuje jednostce względem państwa i jego organów"17. E. Tkaczyk uważa, że "jedną z podstawowych przesłanek istnienia prawa do sądu jako takiego jest zapewnienie jednostce ochrony przed arbitralnością władzy"18. Są to refleksje odnoszące się do teorii prawa, a nie "prawa w działaniu".

Fundamentalne znaczenie dla dalszych analiz ma ustalenie, jak należy poprawnie interpretować użyte przez ustawodawcę pojęcie, jakim jest "sprawa”. K. Gieroń uważa, że powinno być rozumiane szeroko, i przytacza opinię wyrażoną przez Trybunał Konstytucyjny w wyroku z 10 maja 2000 r. ${ }^{19}$, że "pojęcie to nie ma definicji w przepisach Konstytucji RP, a także nie ma jednoznacznego ujęcia w orzecznictwie i doktrynie. Niewątpliwie zakres przedmiotowy prawa do sądu zawiera się w najważniejszej funkcji sądu, jaką jest, zgodnie $\mathrm{z}$ art. 175 ust. 1 Konstytucji RP, sprawowanie wymiaru sprawiedliwości" ${ }^{\prime 20}$.

M. Jaworska - odwołując się do postanowienia Sądu Najwyższego (SN) z 19 grudnia 2003 r. - prezentuje następujące wyjaśnienie: „występujący w art. 45 ust. 1 Konstytucji termin «sprawy» ma charakter autonomiczny i obejmuje nie tylko sprawy cywilne, karne, sądowo-administracyjne, ale także inne, które nimi nie są, a właściwym do orzekania $\mathrm{w}$ tejże materii jest sąd powszechny w postępowaniu

${ }^{16}$ M. Florczak-Wątor, Prawo do sądu jako prawo jednostki i jako gwarancja horyzontalnego działania praw i wolności, „Przegląd Prawa Konstytucyjnego” 2016, nr 3, s. 47-66; O. Hałub-Kowalczyk, M. Jabłoński, M. Radajewski, Identyfikacja treści prawa do sąu - wybrane zagadnienia, Wrocław 2019.

${ }^{17}$ G. Zalizowski, Prawo do sadu na tle Konstytucji Rzeczypospolitej Polskiej w kontekście europejskiej Konwencji o ochronie praw człowieka i podstawowych wolności, w: Duch praw w krajach Europy Środkowo-Wschodniej, pod red. M. Kępy, M. Marszała, Wrocław 2016, s. 17.

${ }^{18}$ E. Tkaczyk, Konstytucyjne prawo do sądu jako jedna z najważniejszych gwarancji praw człowieka w państwie demokratycznym. Aspekt teoretyczny, "Studia Prawnicze i Administracyjne" 2017, nr 20(2), s. 40.

${ }^{19}$ Wyrok TK z dnia 10 V 2000 r., sygn. K 21/99, OTK 2000, nr 4, poz. 109.

${ }^{20} \mathrm{~K}$. Gieroń, Prawo do sadu w orzecznictwie Trybunału Konstytucyjnego i orzecznictwie sadowym, w: "Rodzinna Europa”. Europejska myśl polityczno-prawna u progu XXI wieku, pod red. P. Fitkusa, H. Malewskiego, M. Marszała, Wrocław 2015, s. 559-560. 
cywilnym" ${ }^{\prime 21}$. Przytoczone stanowisko oparte na orzecznictwie upoważnia do sformułowania konkluzji, że pojęcie "sprawy" należy postrzegać oraz interpretować w szerokim kontekście znaczeniowym. Termin ten odnosi się bowiem do zdarzeń, procesów, czynności prawnych oraz decyzji, które dotyczą danej jednostki i mają dla niej znaczenie - są ważne, gdyż wywołują określone skutki prawne, naruszają konstytucyjne gwarancje, rodzą określone konsekwencje finansowe, społeczne, środowiskowe, zdrowotne itp. W orzecznictwie podkreśla się, że prawo do sądu ma autonomiczny charakter, gdyż jest niezależne i odrębne od innych rozwiązań normatywnych ${ }^{22}$. Sąd Najwyższy w postanowieniu z 21 maja 2002 r. stwierdził ponadto, iż "w praktyce oznacza to, że sprawa przedstawiona do rozstrzygnięcia musi być przez sąd (powszechny lub inny) rzeczywiście rozpoznana"23.

W świetle powyższych przesłanek uzasadnione jest stwierdzenie, że obywatel może zwrócić się do właściwego sądu, gdy poszukuje sprawiedliwości w kontekście rozpatrzenia każdej sprawy, która ma dla niego znaczenie. Niewątpliwie jednym z istotnych zagadnień są kwestie dotyczące zatrudnienia, m.in. $w$ aspekcie szans zdobycia pracy, możliwości otrzymania intratnej posady, obejmowania stanowisk, pełnienia funkcji w państwowych instytucjach itd. Ta materia ma ścisły związek z przepisami prawa, które wyznaczają ramy i określają tryb podejmowania decyzji kadrowych w przedmiotowym zakresie.

Jak słusznie zauważa Rzecznik Praw Obywatelskich (RPO), "naruszenia konstytucyjnej zasady równego traktowania i zakazu dyskryminacji to przede wszystkim problemy obywateli" ${ }^{\prime 2}$. Zgadzając się w pełni z tą refleksją, godzi się jedynie dodać, że takie bariery i utrudnienia nie dotykają wszystkich obywateli w jednakowym stopniu. Praktyka dostarcza bowiem niezliczonych przykładów wskazujących na to, że społeczeństwo dzieli się na grupę osób mających korzystniejszą pozycję, prawa i przywileje, a także zwykłych obywateli marginalizowanych, wykluczanych i traktowanych w odmienny sposób. Oczywiście w oficjalnych dokumentach znajdują się odwołania do teorii prawa podkreślające, że "nakaz równego

${ }^{21}$ M. Jaworska, Prawo do sądu, w: Realizacja i ochrona konstytucyjnych wolności i praw w polskim porządku prawnym, pod red. M. Jabłońskiego, Wrocław 2014, s. 143-144.

${ }^{22}$ K. Gieroń, op. cit., s. 564.

${ }^{23}$ Postanowienie SN z 21 V 2002 r., sygn. III CK 53/02, OSNC 2003, nr 2, poz. 31.

${ }^{24}$ Informacja o działalności Rzecznika Praw Obywatelskich w obszarze równego traktowania za rok 2018 oraz o przestrzeganiu zasady równego traktowania w Rzeczypospolitej Polskiej, 25 XII 2019 r., s. 3, https://www.rpo.gov.pl/pl/content/informacja-roczna-rpo-z-zakresu-rownego-traktowania-w-2018 (dostęp: 15 I 2020). 
traktowania zajmuje eksponowane miejsce zarówno w regulacjach krajowych, jak i w aktach prawa międzynarodowego", akcentujące jednocześnie, że "równość wobec prawa stanowi jedną z fundamentalnych zasad ochrony praw człowieka, a jej przestrzeganie warunkuje realizację innych praw podstawowych" ${ }^{25}$. Zdaniem RPO "zgodnie z utrwalonym orzecznictwem Trybunału Konstytucyjnego, zasada równości wyrażona w art. 32 Konstytucji RP oznacza, że wszystkie podmioty prawa (adresaci norm prawnych) charakteryzujący się daną cechą istotną (relewantną) w równym stopniu powinny być traktowane równo, według jednakowej miary, bez zróżnicowań dyskryminujących lub faworyzujących"26. Nie zmienia to jednak faktu, że sformułowania te nie znajdują potwierdzenia w codziennej rzeczywistości organizacyjnej oraz w praktyce zarządzania.

Konstytucyjna norma, mająca stanowić gwarancję równego traktowania jednostki przez władze publiczne, a także prawo do rozpatrzenia sprawy przed sądem, w wielu przypadkach pozostają jedynie w sferze deklaratywnej. Dostarczając merytorycznych oraz niedających się podważyć argumentów uzasadniających słuszność wyrażonej oceny, zasadne będzie w tym miejscu odwołanie się do konkretnych przykładów. W dalszych rozważaniach zostaną poddane analizie decyzje kadrowe przesądzające o możliwości otrzymania zatrudnienia, tj. podjęcia pracy w wybranych instytucjach państwowych ${ }^{27}$, które ze względu na zakres swojej działalności oraz inne okoliczności są w ostatnim czasie przedmiotem licznych dyskusji w przestrzeni publicznej. Przyjęta formuła prowadzonych czynności analitycznych sprowadza się do udzielenia odpowiedzi na postawione pytania.

- Czy wszyscy polscy obywatele korzystający z pełni praw publicznych mają jednakowe prawa i są równo traktowani w procesie doboru kadr na funkcje wiceprezesów Najwyższej Izby Kontroli (NIK), dyrektora generalnego NIK, dyrektorów departamentów, a także na pozostałe stanowiska inne niż kontrolerskie, zważywszy na to, że tylko w ostatnim przypadku obowiązują tzw. zasady otwartego i konkurencyjnego naboru?

${ }^{25}$ Ibidem, s. 5 .

${ }^{26}$ Ibidem.

${ }^{27}$ Analogiczne pytania można sformułować w odniesieniu do służby cywilnej, wszystkich organizacji sektora finansów publicznych, spółek komunalnych, spółek z udziałem Skarbu Państwa oraz innych państwowych osób prawnych, NBP, fundacji utworzonej przez spółki Skarbu Państwa, organizacji pozarządowych, prywatnych podmiotów itd. 
Analiza aktualnych przepisów upoważnia do stwierdzenia, że potencjalnie zainteresowani zdobyciem zatrudnienia w NIK na wyżej wymienionych stanowiskach nie mają jednakowego prawa w zakresie możliwości ubiegania się o podjęcie pracy. Co więcej, nie mają żadnych podstaw prawnych do tego, aby dochodzić swoich roszczeń z tytułu naruszenia zasady równego traktowania na drodze sądowej. Oznacza to, że posiadając wymagane kwalifikacje formalne, jeśli samodzielnie podejmą próbę pisemnego wystąpienia $\mathrm{z}$ taką aplikacją do osoby posiadającej stosowne kompetencje decyzyjne, są z góry na straconej pozycji, bo nikt nie będzie ich traktował poważnie. $W$ rezultacie takie podanie zostanie zignorowane, a wszystko odbędzie się zgodnie z prawem. W przypadku procesów decyzyjnych $w$ zakresie przyjęcia do pracy w NIK niemożliwe jest domaganie się rozpatrzenia takiej sprawy przez sąd, kontroli sądowej mogą zaś być poddane decyzje kadrowe związane ze zmianą warunków umowy bądź rozwiązaniem stosunku pracy. Warto w tym miejscu dodać, że zasady te dotyczą wszystkich rekrutacji, z tą jedną drobną różnica, że w przypadku doboru osób na stanowiska kontrolerskie występują równe prawa w zakresie możliwości zgłoszenia swojej kandydatury i wzięcia udziału $\mathrm{w}$ postępowaniu prowadzonym przez komisję konkursową. Ponadto tylko dla kontrolerów wymagane są testy z wiedzy ogólnej, znajomości języka obcego i kompetencji, podczas gdy w odniesieniu do pozostałych miejsc pracy nie obowiązują takie zasady. Ostateczna decyzja w sprawie zatrudnienia należy do wyłącznej kompetencji prezesa NIK, jest ostateczna, wiążąca i nie podlega zaskarżeniu. Opisane procedury i działania są zgodne z przepisami ustawy o NIK z dnia 23 grudnia $1994 \mathrm{r}^{28}{ }^{2}$, co sprawia, że nie można kwestionować ich legalności.

Biorąc pod uwagę fakt, że „praca w NIK to służba Rzeczypospolitej i społeczeństwu" ${ }^{\prime 2}$, można przyjąć szerszą perspektywę rozumowania odwołującą się wprost do treści art. 60 Konstytucji RP: „Obywatele polscy korzystający z pełni praw publicznych mają prawo dostępu do służby publicznej na jednakowych zasadach", w powiązaniu z treścią art. 2 ustawy zasadniczej: „Rzeczpospolita jest demokratycznym państwem prawnym, urzeczywistniającym zasady sprawiedliwości społecznej".

${ }^{28}$ Tekst jedn. Dz.U. 2019, poz. 489 ze zm.

29 „Jeżeli [...] posiadają Państwo wymagane wykształcenie, doświadczenie oraz kompetencje kontrolera NIK i chcą mieć realny wpływ na to, co dzieje się w Polsce - praca w NIK czeka na Państwa", Praca w NIK, https://www.nik.gov.pl/praca-w-nik/ (dostęp: 15 I 2020). 
Takie analityczne podejście kładzie nacisk na myślenie w kategorii gwarancji obywatelskich, wolności i praw człowieka, a kryteria oceny są nasycone konstytucyjną aksjologią. Ma ono również swój szerszy wydźwięk znaczeniowy.

- Czy wszyscy polscy obywatele korzystający z pełni praw publicznych mają równe prawa dostępu i są jednakowo traktowani w procedurze ubiegania się o pracę na stanowisku zastępców Rzecznika Praw Obywatelskich $^{30}$, podobnie jak w procesach rekrutacji na pozostałe miejsca pracy w Biurze RPO, kiedy tylko selektywna informacja o naborze na niektóre stanowiska jest podawana w Biuletynie Informacji Publicznej ${ }^{31}$ ?

Obowiązujące przepisy sprawiają, że potencjalnie zainteresowani objęciem funkcji zastępcy RPO nie mają prawa i gwarancji jednakowego traktowania $\mathrm{w}$ zakresie możliwości ubiegania się o podjęcie pracy na takim stanowisku w instytucji, która zajmuje się dbaniem o przestrzeganie wolności i praw człowieka ${ }^{32}$. Takim osobom nie przysługuje też opisywane w Konstytucji prawo do sądu, jeśli z własnej inicjatywy podejmą próbę zgłoszenia swojej kandydatury, a ich podanie zostanie zignorowane i pozostawione bez rozpatrzenia. Kandydaci biorący udział w naborach, którzy nie zostali wybrani do pracy, także nie mają możliwości zaskarżenia takiej sprawy do sądu. Wszystkie procesy kadrowe w biurze RPO są realizowane na podstawie obowiązującego prawa i tym samym ich legalność nie może być podważana. Ostateczne i wiążące decyzje w sprawach przyjęcia do pracy należą do wyłącznej kompetencji Rzecznika i nie podlegają zaskarżeniu.

- Czy wszyscy polscy obywatele korzystający z pełni praw publicznych i posiadający stosowne kwalifikacje formalne mają równe prawa dostępu i są jednakowo traktowani w procedurze ubiegania się o urząd sędziego?

${ }^{30}$ Zastępcy RPO, https://www.rpo.gov.pl/content/zastępcy-rpo (dostęp: 15 I 2020).

${ }^{31}$ Praca w biurze RPO, http://bip.brpo.gov.pl/pl/category/praca (dostęp: 15 I 2020).

32 "Rzecznik Praw Obywatelskich stoi na straży wolności i praw człowieka i obywatela, w tym realizacji zasady równego traktowania", Czym zajmuje się Rzecznik Praw Obywatelskich?, https://www.rpo.gov.pl/content/dzialalnosc-rzecznika-praw-obywatelskich; zob. też Nasze konstytucyjne prawa, https://www.rpo.gov.pl/konstytucja (dostęp: 15 I 2020). 
Z wyjątkiem procedury wyboru sędziów Trybunału Konstytucyjnego, w przypadku pozostałych sądów wszystkie osoby zainteresowane pracą na stanowisku sędziego mają zagwarantowane równe prawa w zakresie możliwości ubiegania się o pełnienie tego zaszczytnego urzędu. Ponadto występuje tutaj istotna różnica w stosunku do wcześniej analizowanych procesów kadrowych, gdyż w przypadku uchwał Krajowej Rady Sądownictwa (KRS) negatywnie ocenionym osobom przysługuje prawo odwołania się od podjętej decyzji do sądu. Takie rozwiązanie dotyczy kwestii rozpatrzenia sprawy, $\mathrm{tj}$. zaskarżenia uchwały w przedmiocie wyboru na stanowisko sędziowskie w sądach powszechnych. Warto w tym miejscu przypomnieć, że w ubiegłym roku na mocy wyroku Trybunału Konstytucyjnego z 25 marca 2019 r. stwierdzono niezgodność art. 44 ust. 1a ustawy o Krajowej Radzie Sądownictwa z art. 184 Konstytucji ${ }^{33}$ (odnoszącego się do odwołania od uchwały KRS dotyczącej wyboru na stanowisko sędziego Sądu Najwyższego), a jednocześnie uznano, że "art. 9a ustawy z dnia 12 maja 2011 r. o Krajowej Radzie Sądownictwa (Dz.U. z 2019 r. poz. 84) jest zgodny z art. 187 ust. 1 pkt 2 i ust. 4 w związku z art. 2, art. 10 ust. 1 i art. 173 oraz z art. 186 ust. 1 Konstytucji Rzeczypospolitej Polskiej"34.

Nie ulega wątpliwości, że najważniejszą rolę w procesie decyzyjnym przesądzającym o możliwości objęcia stanowiska sędziowskiego, a także awansowania do sądu wyższej instancji, spełnia KRS, która de facto jest komisją konkursową. Jej skład osobowy jest nie do przecenienia, kształtuje bowiem dokonywane rozstrzygnięcia - podejmuje kolegialne decyzje $w$ formie uchwał poprzez głosowanie. Nie trzeba w tym miejscu tłumaczyć, jak istotne są nominacje sędziowskie do SN, mają bowiem fundamentalne znaczenie nie tylko z punktu widzenia KRS, ale całego systemu sądownictwa w Polsce. Nie można jednak zapominać, że wszystkie decyzje o charakterze kadrowym (również inne czynności prawne) pozostają pod wpływem synergicznego oddziaływania wielu czynników o charakterze endogenicznym, a także egzogenicznym. To, że działania podejmowane są na podstawie obowiązującego prawa przez upoważniony do tego organ, absolutnie nie oznacza, że są

${ }^{33}$ Zob. wyrok TK z 25 III 2019 r., sygn. K12/18, Wybór członków KRS przez Sejm spośród sędziów; odwołanie od uchwały KRS dotyczacej powołania do petnienia urzędu na stanowisku sędziego, http://trybunal.gov.pl/postepowanie-i-orzeczenia/wyroki/art/10521-wyborczlonkow-krs-przez-sejm-sposrod-sedziow-odwolanie-od-uchwaly-krs-dotyczacej-powola/ (dostęp: 15 I 2020).

${ }^{34}$ Ibidem. 
bezstronne, obiektywnie uzasadnione, uczciwe i sprawiedliwe ${ }^{35}$. Dlatego też trzeba uznać, że sformułowana konstatacja ma walor ponadczasowy i nie odnosi się wyłącznie do członków KRS ukształtowanej według nowej ustawy, ale ma zastosowanie także do decyzji sędziów zasiadających w poprzednich składach komisji konkursowej - analogicznie jest w przypadku wszystkich decyzji podejmowanych przez inne organy władzy publicznej oraz przez piastunów władzy w prywatnych przedsiębiorstwach, organizacjach pozarządowych i pozostałych podmiotach gospodarczych ${ }^{36}$.

Analizując poczynania władzy sędziowskiej po wyroku TSUE z 19 listopada 2019 r., trzeba przyjąć holistyczne podejście, które przybliża do identyfikacji źródeł występowania odmiennych interpretacji z uwzględnieniem ich konsekwencji dla zainteresowanych stron. W pierwszej kolejności warto zwrócić uwagę na główną sentencję rozstrzygnięcia, gdyż bezpośrednio nawiązuje ona do wcześniejszych rozważań na temat równego traktowania i praw jednostki. Wyrok dotyczy bowiem stosowania prawa Unii Europejskiej (UE) w kontekście interpretacji ogólnych warunków ramowych w zakresie zatrudnienia i pracy ${ }^{37}$. Oczywiście zadane przez Izbę Pracy SN pytania prejudycjalne, które dały asumpt do wydania orzeczenia przez TSUE, dotyczyły wykładni interpretacyjnej

${ }^{35}$ Niedopuszczalne jest rozpatrzenie zgłoszeń jedynie wybranych osób spośród wszystkich aplikujących na wolne stanowisko sędziego SN, gdyż byłoby to rażące naruszenie prawa do równego traktowania, pogwałcenie zasad praworządności i zasad sprawiedliwości społecznej. Metodyka kontaktu jedynie z wybranymi kandydatami jest natomiast prawnie dopuszczalna w sytuacji, gdy dotyczy postępowania i decyzji kadrowych SN względem zwykłych obywateli. Szerzej zob. Rekrutacja na stanowisko Kierownika Zespołu do Obsługi Sędziów w Biurze Gospodarczym Izby Dyscyplinarnej Sądu Najwyższego, 11 XII 2019; Sąd Najwyższy informuje, że "[z]astrzega się kontakt z wybranymi kandydatami", http://www.sn.pl/informacjepraktyczne/SitePages/Ogloszenia.aspx?ItemSID=25-8480cc0a-f675-4b34-b408-af62bdc205a9\&ListName=Ogloszenia (dostęp: 20 XII 2019).

${ }^{36}$ W. Walczak, Przestępstwa korupcyjne a legalna korupcja - aspekty ekonomiczne i prawne, „Przegląd Bezpieczeństwa Wewnętrznego" 2019, nr 21, s. 44-81.

37 "Artykuł 47 Karty praw podstawowych Unii Europejskiej i art. 9 ust. 1 dyrektywy Rady 2000/78/WE z dnia 27 XI 2000 r. ustanawiającej ogólne warunki ramowe równego traktowania w zakresie zatrudnienia i pracy należy interpretować w ten sposób, że stoją one na przeszkodzie temu, by spory dotyczące stosowania prawa Unii mogły należeć do wyłącznej właściwości organu niestanowiącego niezawisłego i bezstronnego sądu w rozumieniu pierwszego z tych przepisów. Do sądu odsyłającego należy ustalenie, przy wzięciu pod uwagę wszystkich istotnych informacji, którymi dysponuje, czy jest tak w przypadku organu takiego jak Izba Dyscyplinarna Sądu Najwyższego". Szerzej zob. przywoływany wyrok TSUE z 19 XI 2019 r. 
praw obywatela zajmującego stanowisko sędziego NSA. Po drugie, krytyczna refleksja ma temat wiedzy o prawie ${ }^{38}$ nakazuje zauważyć, że sędziowie mogą dokonywać swobodnej interpretacji tekstu prawnego, co w rezultacie prowadzi do rozbieżnych ustaleń i wniosków. Dlatego też powszechną akceptację zyskuje pogląd, że prawo w teorii oraz stosowanie prawa $\mathrm{w}$ praktyce to dwa odrębne byty i zagadnienia problemowe $^{39}$. Prawo w teorii jest postrzegane jako "norma sankcjonowana przez społeczną siłę przymusu" ${ }^{\prime \prime}$, natomiast prawo w działaniu jest pochodną deskryptywnej interpretacji ${ }^{41}$ przepisów dokonywanej przez organy stosujące prawo.

\section{Wyrok Trybunału Sprawiedliwości Unii Europejskiej z 19 listopada 2019 r. - interpretacja Sądu Najwyższego, Ministerstwa Sprawiedliwości oraz Krajowej Rady Sądownictwa}

Sąd Najwyższy, rozpatrując w składzie trzyosobowym indywidualną sprawę dotyczącą odwołania od uchwały Krajowej Rady Sądownictwa zawierającej negatywną opinię $w$ przedmiocie dalszego zajmowania stanowiska przez sędziego Naczelnego Sądu Administracyjnego, w wyroku wydanym 5 grudnia 2019 r. w Izbie Pracy i Ubezpieczeń Społecznych (sygn. III PO 7/18) ${ }^{42}$ oddalił wniosek prezesa Izby Dyscyplinarnej Sądu Najwyższego z 10 października 2018 r. o przekazanie sprawy według właściwości do Izby Dyscyplinarnej, a także uchylił uchwałę KRS z dnia 27 lipca 2018 r. w przedmiocie dalszego zajmowania

${ }^{38}$ P. Jabłoński, M. Pichlak, Miejsce refleksji krytycznej w instytucjonalnej wiedzy o prawie, „Principia” 2013, nr 57-58, s. 269-295.

${ }^{39}$ Meandry prawa - teoria i praktyka. Ksiega jubileuszowa prof. zw. dra hab. Mieczysława Goettela, pod red. E. Pływaczewskiego, J. Bryka, Szczytno 2017; Tworzenie a stosowanie prawa w Polsce. Teoria i praktyka, pod red. M. Mazuryka, D. Kotłowskiego, K. Sadowskiego, Warszawa 2014.

${ }^{40}$ A.F. Utz, Pojęcie prawa w teorii i praktyce, "Roczniki Nauk Prawnych” 2010, nr 2, s. 8.

${ }^{41} \mathrm{P}$. Jabłoński, O deskryptywnym poziomie interpretacji tekstu prawnego, "Studia Prawno-Ekonomiczne" 2018, nr 106, s. 29-53.

${ }^{42}$ Komunikaty o sprawach. Uzasadnienie wyroku z 5 grudnia 2019 r., w którym SN uznał, że Izba Dyscyplinarna SN nie jest sądem w rozumieniu prawa UE, a obecna KRS nie jest organem bezstronnym i niezawisłym, 20 XII 2019, http://www.sn.pl/ aktualnosci/SitePages/Komunikaty_o_sprawach.aspx?ItemSID=331-b6b3e8042752-4c7d-bcb4-7586782a1315\&ListName=Komunikaty_o_sprawach (dostęp: 20 XII 2019). 
stanowiska sędziego NSA przez A.K. Co ważne, w komunikacie przybliżającym uzasadnienie omawianego wyroku na stronie internetowej podano do publicznej wiadomości następujący przekaz informacyjny: Sąd Najwyższy uznał, że „Izba Dyscyplinarna SN nie jest sądem w rozumieniu prawa UE, a obecna KRS nie jest organem bezstronnym i niezawisłym"43. W uzupełnieniu wskazano ponadto główne motywy podjętego rozstrzygnięcia ${ }^{44}$.

Na szczególną uwagę i wnikliwe omówienie zasługują dodatkowe merytoryczne argumenty wskazane przez skład orzekający SN, jakie miały wpływ na wydane rozstrzygnięcie. Poniżej przedstawiono stwierdzenia najważniejsze dla analizowanego problemu badawczego. Sąd Najwyższy w uzasadnieniu wyroku z 5 grudnia 2019 r. (sygn. III PO 7/18) przedstawił m.in. kolejne wyjaśnienia, które wymagają poważnego komentarza.

- "Gdy regulacja krajowej ustawy jest zgodna z krajową regulacją konstytucyjna, a jednocześnie jest sprzeczna z prawem unijnym, odmowa zastosowania przepisów krajowej ustawy nie może budzić żadnych kontrowersji ani zastrzeżeń ze strony prawa konstytucyjnego,

${ }^{43}$ Ibidem.

${ }^{44}$ Motywy te sprowadzają się do ośmiu najważniejszych tez:

1. wykładnia zawarta w wyroku TSUE z 19 listopada 2019 r. wiąże każdy sąd w Polsce, a także każdy organ władzy państwowej;

2. wyrok TSUE wyznacza jednoznaczny i precyzyjny standard oceny niezawisłości i bezstronności sądu, jaki obowiązuje we wszystkich krajach Unii Europejskiej, w tym w Polsce;

3. każdy sąd w Polsce, w tym Sąd Najwyższy, ma obowiązek z urzędu badać, czy standard przewidziany w wyroku TSUE jest zapewniony w rozpoznawanej sprawie;

4. wykonując ten obowiązek, Sąd Najwyższy stwierdził, że Krajowa Rada Sądownictwa w obecnym składzie nie jest organem bezstronnym i niezawisłym od władzy ustawodawczej i wykonawczej;

5. Sąd Najwyższy uznaje, że Izba Dyscyplinarna Sądu Najwyższego nie jest sądem w rozumieniu prawa Unii Europejskiej, a przez to nie jest sądem w rozumieniu prawa krajowego;

6. Polska, przystępując do Unii Europejskiej, zgodziła się na zasadę pierwszeństwa prawa unijnego nad prawem krajowym (co zostało przypomniane w pkt 157 wyroku TSUE);

7. prymat prawa Unii skutkuje tym, że każdy organ państwa członkowskiego ma obowiązek zapewnić pełną skuteczność norm prawa Unii (pkt 158 wyroku TSUE), aż do pomijania niezgodnych przepisów prawa krajowego (pkt 160).

8. dlatego Sąd Najwyższy z pominięciem Izby Dyscyplinarnej rozpoznał merytorycznie sprawę powoda. 
gdyż nie prowadzi do wydania orzeczenia, które byłoby niezgodne z ustawą zasadniczą" 45 .

Warto w tym miejscu zauważyć, że tzw. zasada legalizmu wyrażona w art. 7 Konstytucji RP: „[o]rgany władzy publicznej działają na podstawie i w granicach prawa", bezwarunkowo obliguje organy władzy do podejmowania działań na podstawie prawa oraz nakłada powinność przestrzegania prawa. Nie powinno budzić wątpliwości stwierdzenie, że obowiązek ten ma charakter fundamentalny dla istnienia państwa prawa, a także z punktu widzenia urzeczywistniania reguł praworządności. Co więcej, w myśl art. 9 Konstytucji „Rzeczpospolita Polska przestrzega wiążącego ją prawa międzynarodowego", natomiast zgodnie z art. 8 ust. 1 to „Konstytucja jest najwyższym prawem Rzeczypospolitej Polskiej", a nie wybrane przepisy prawa międzynarodowego. Przepis art. 8 jest wysoce czytelny, klarowny i jednoznaczny, co oznacza, że nie powinno się dokonywać nieuprawnionej nadinterpretacji, zważywszy dodatkowo na fakt, że "przepisy Konstytucji stosuje się bezpośrednio, chyba że Konstytucja stanowi inaczej" (art. 8 ust. 2). Dodatkowym argumentem prawnym jest przepis Konstytucji, który enumeratywnie wskazuje gradację źródeł prawa i rozstrzyga sporną kwestię, a mianowicie art. 87 ust. 1, w myśl którego „[ź]ródłami powszechnie obowiązującego prawa Rzeczypospolitej Polskiej są: Konstytucja, ustawy, ratyfikowane umowy międzynarodowe oraz rozporządzenia". Z kolei art. 83 Konstytucji wprost określa, że "każdy ma obowiązek przestrzegania prawa Rzeczypospolitej Polskiej". Z brzmienia cytowanego przepisu jasno wynika, że w ustawie zasadniczej nie przewidziano odstępstwa od tego nakazu, a mianowicie tego, że nie dotyczy on przedstawicieli władzy sądowniczej, Prezydenta RP bądź prominentnych reprezentantów władzy wykonawczej, ustawodawczej, o czym koniecznie należy pamiętać.

- „Litera prawa nie ma decydującego znaczenia dla oceny, czy organ taki jak nowa KRS działa w sposób wystarczająco niezależny od władzy wykonawczej i ustawodawczej. Liczy się praktyka i cały złożony kontekst otoczenia prawnego i faktycznego, w jakim dochodzi do wykonywania przez ten organ jego konstytucyjnych kompetencji"46.

Dokonując bezstronnej i obiektywnej oceny stanowiska wyrażonego przez skład orzekający SN, trzeba zgodzić się z poglądem, że przesłanki

\footnotetext{
${ }^{45}$ Uzasadnienie wyroku SN z 5 XII 2019 r., sygn. III PO 7/18, s. 20.

${ }^{46}$ Ibidem, s. 24.
} 
i kryteria brane pod uwagę podczas rozpatrywania kwestii niezależności organu wymagają przyjmowania szerszej perspektywy myślowej. Ta refleksja nie może jednakże stanowić samoistnej podstawy do kwestionowania decyzji podejmowanych przez dany organ, jeśli są one zgodne $\mathrm{z}$ obowiązującymi przepisami uchwalonego prawa $\mathrm{w}$ świetle wcześniej przywoływanych argumentów, odwołujących się wprost do cytowanych postanowień Konstytucji RP.

- „Fakt wręczenia przez Prezydenta RP nominacji na stanowisko sędziowskie w reakcji na wniosek nowej KRS o powołanie na stanowisko sędziowskie nie zwalnia każdego sądu z oceny, czy tak ukonstytuowany sąd jest sądem w rozumieniu prawa Unii, Konwencji oraz prawa krajowego (art. 45 Konstytucji RP). Przedmiotem oceny nie jest bowiem ważność (skuteczność) aktu nominacji Prezydenta $R P$, lecz percepcja sądu ukonstytuowanego przy udziale nowej KRS jako sądu niezależnego od władzy ustawodawczej i wykonawczej"47. Z takiego sformułowania SN jasno wynika, że wszystkie sądy w Polsce miałyby przyznane prawo do oceniania poprawności wyboru składu sędziowskiego wyznaczonego do rozpoznania danej sprawy - odwołując się do przepisu art. 45 Konstytucji RP - jeśli zasiada w nim osoba, która otrzymała nominację na stanowisko sędziego na wniosek nowej KRS. Gdyby ten tok rozumowania i sposób interpretacji prawa zaprezentowany przez SN przyjąć za słuszny oraz prawidłowy, wówczas oznaczałoby to również możliwość podważania wyroków, orzeczeń, w których brali udział sędziowie wskazani do objęcia swoich funkcji przez KRS działającą na podstawie znowelizowanej ustawy. A zatem ważność nominacji sędziowskich dokonywanych przez Prezydenta RP wyłącznie w teorii nie byłaby kwestionowana, natomiast w praktyce fakt skutecznego i legalnego powołania na stanowisko sędziowskie przez Prezydenta RP nie stanowiłby jakiejkolwiek przeszkody od strony formalnoprawnej, aby można było podważać uprawnienia orzecznicze danego sędziego. W konsekwencji taka sytuacja mogłaby doprowadzić do poważnej destabilizacji wymiaru sprawiedliwości i zasad praworządności, a przede wszystkim stanowić realne zagrożenie dla bezpieczeństwa prawnego obywateli. Zdecydowanie inny punkt widzenia zawarto w uzasadnieniu SN.

${ }^{47}$ Ibidem. 
- „Tylko po uprzednim zapewnieniu sądowej kontroli działania takiego organu jak KRS, można mówić o tym, że dana osoba została prawidłowo (to jest zgodnie z prawem) przedstawiona Prezydentowi RP z wnioskiem o powołanie i została legalnie nominowana przez głowę państwa do pełnienia służby" 48 .

Dodatkowa argumentacja prawna przywoływana przez SN zawiera niezwykle wymowną konstatację, że „w zakresie dotyczącym składu KRS i zasad jego wyłaniania postanowienia Konstytucji RP nie uległy żadnym zmianom. Oznacza to, że w trybie ustawy uprawnione było jedynie skorygowanie metody wyboru członków Rady (sędziów) przez sędziów, a nie wprowadzenie trybu wyboru sędziów-członków KRS przez władzę ustawodawczą ${ }^{\prime \prime 9}$. Prawdą jest niedający się zaprzeczyć fakt, że postanowienia Konstytucji w przedmiotowym zakresie pozostają niezmienione, natomiast sugerowanie, jakoby w ustawie zasadniczej był przepis określający zasady wyłaniania składu organu, który nakazuje dokonywanie wyboru członków KRS (sędziów) przez sędziów, stanowi świadomie czynione nadużycie interpretacyjne. Biorąc pod uwagę stan faktyczny, godzi się w tym miejscu przypomnieć i zacytować treść art. 187 ust. 4 ustawy zasadniczej: „Ustrój, zakres działania i tryb pracy Krajowej Rady Sądownictwa oraz sposób wyboru jej członków określa ustawa". Można powiedzieć, że nastąpiła nowelizacja ustawy o KRS, w której zgodnie z art. 187 ust. 4 Konstytucji dokonano modyfikacji w zakresie dotychczasowej procedury wyłaniania piętnastu sędziów KRS. Nie daje się zanegować tego, że w rezultacie wprowadzonych zmian elitarna, zorganizowana oraz współdziałająca ze sobą grupa sędziów (tj. osoby wchodzące w skład poprzedniej KRS, a także pełniące uprzednio funkcje prezesów i wiceprezesów sądów, osoby zasiadające we władzach sędziowskich stowarzyszeń) utraciła znaczną część posiadanych wpływów, dających możliwość oddziaływania i przejmowania kontroli nad procesem doboru kadr w polskim sądownictwie (powoływania nowych sędziów, awansowania). Zdaniem SN wybrani nowi członkowie KRS są beneficjentami wprowadzonej reformy wymiaru sprawiedliwości, a także zajmują stanowiska kierownicze w sądach, w których uprzednio odwołano prezesów i wiceprezesów ${ }^{50}$. Są to słuszne spostrzeżenia, gdyż nie można temu zaprzeczyć.

\footnotetext{
${ }^{48}$ Ibidem, s. 24-25.

${ }^{49}$ Ibidem, s. 33.

${ }^{50}$ Ibidem, s. 37.
} 
Interesujące poznawczo i wysoce znamienne jest stanowisko SN na temat procesu wyłonienia członków obecnej KRS, a w szczególności list poparcia dla kandydatów.

- „Do tej pory nie zweryfikowano, czy członkowie zostali zgłoszeni zgodnie z prawem ani kto udzielił im poparcia. Stosowne dokumenty nie zostały do tej pory ujawnione mimo wydanego $w$ tej sprawie wyroku przez Naczelny Sąd Administracyjny w dniu 28 czerwca $2019 \mathrm{r}^{51}$ Jak wiadomo, wykonaniu orzeczenia stoi na przeszkodzie decyzja Prezesa Urzędu Ochrony Danych Osobowych (UODO) z dnia 29 lipca 2019 r., której wydanie zostało zainicjowane przez jednego z członków nowej KRS"52.

Zaprezentowane stanowisko SN wyraźnie wskazuje, że ujawnienie list poparcia uniemożliwia decyzja Prezesa UODO, co musi skłaniać do refleksji i zastanowienia, taka bowiem interpretacja de facto uzasadnia fakt ignorowania przez Kancelarię Sejmu RP prawomocnego wyroku $\mathrm{NSA}^{53}$. Jest to o tyle zdumiewające, że organy władzy publicznej mają

${ }^{51}$ OSK 4282/18, LEX nr 2694019.

${ }^{52}$ Uzasadnienie wyroku SN z 5 XII 2019 r., sygn. III PO 7/18, s. 35.

${ }^{53}$ Prawne zablokowanie ujawnienia list poparcia kandydatów do nowej KRS jest tak ważnym i newralgicznym problemem, że ponownie grupa posłów z partii rządzącej w nowej kadencji Sejmu 2 grudnia 2019 r. wystąpiła z wnioskiem do Trybunału Konstytucyjnego o zbadanie zgodności:

- art. 11c Ustawy z dnia 12 maja 2011 r. o Krajowej Radzie Sądownictwa (tekst jedn. Dz.U. 2019, poz. 84 ze zm.) rozumianego w ten sposób, że przepis ten nie zakazuje udzielenia informacji publicznej w postaci wykazu sędziów, popierających zgłoszenie kandydata na członka KRS wybieranego spośród sędziów z art. 2 Konstytucji RP, tj. zasadą ochrony zaufania obywateli do państwa i stanowionego przez nie prawa, art. 47 Konstytucji RP, tj. gwarantowaną w Konstytucji RP zasadą ochrony prawa do prywatności, art. 51 Konstytucji RP, gwarantującym w Konstytucji RP tzw. ochronę autonomii informacyjnej jednostki;

- art. 5 ust. 2 Ustawy z dnia 6 września 2001 r. o dostępie do informacji publicznej (tekst jedn. Dz.U. 2019, poz. 1429), rozumianego w ten sposób, że wyrażenie przez sędziego poparcia dla kandydata do KRS ma związek z wykonywaniem przez sędziego wyrażającego takie poparcie funkcji publicznych, a zatem dostęp do takiej informacji nie podlega ograniczeniu ze względu na ochronę prywatności tego sędziego, z art. 47 Konstytucji RP, tj. zagwarantowaną w Konstytucji RP zasadą ochrony prawa do prywatności i art. 51 Konstytucji RP gwarantującym w Konstytucji RP tzw. ochronę autonomii informacyjnej jednostki.

Szerzej zob. Art. 11c ustawy o Krajowej Radzie Sadownictwa i art. 5 ust. 2 ustawy o dostepie do informacji publicznej (sygn. K 21/19), http://trybunal.gov.pl/sprawy-w-trybunale/art/ art-11c-ustawy-o-krajowej-radzie-sadownictwa-i-art-5-ust-2-ustawy-o-dostepie-do-informacji-publicznej (dostęp: 20 XII 2019). 
bezdyskusyjny obowiązek respektowania i stosowania się do prawomocnych rozstrzygnięć władzy sądowniczej. Na uwagę zasługuje ponadto informacja na temat działań podejmowanych przez sędziego będącego członkiem nowej KRS, które miały związek przyczynowo-skutkowy z wydaną decyzją administracyjna, mającą na celu utajnienie przed opinią publiczną nazwisk sędziów popierających kandydatów do nowej KRS ${ }^{54}$.

Skład orzekający SN dodatkowo wyjaśnia, iż "faktem powszechnie znanym jest uzyskiwanie przez opinię publiczną informacji, że sędziów do Rady rekomendowali prezesi sądów rejonowych powołani przez Ministra Sprawiedliwości, zgłaszali też sędziowie zależni (podlegli) kandydatowi zajmującemu stanowisko kierownicze w sądzie wyższej instancji, sędziów do Rady zgłaszał pełnomocnik Instytutu Wymiaru Sprawiedliwości przy Ministerstwie Sprawiedliwości, w końcu kandydatów zgłaszały osoby bliskie, sam kandydat zgłaszał innego kandydata, a niektórzy z wybranych członków przyszłej Rady pracowali w Ministerstwie Sprawiedliwości" ${ }^{\prime \prime 5}$.

Co ważne, sąd nie uzasadnia swojego wywodu na bazie wyników przeprowadzonej analizy materiału dowodowego zgromadzonego i ujawnionego w toku prowadzonego postępowania, lecz odwołuje się do publicznie dostępnych informacji medialnych, m.in. do enuncjacji podawanych przez krytykujący obecną władzę portal OKO.press ${ }^{56}$. Na dwa dni przed wydanym w Izbie Pracy i Ubezpieczeń Społecznych SN wyrokiem, 3 grudnia 2019 r. portal ten opublikował materiał analizujący powiązania sędziów nowej KRS (określanej mianem neo-KRS)

${ }^{54}$ Opisywana sytuacja w ostatnim czasie uległa zmianie, gdyż 14 lutego 2020 r. Kancelaria Sejmu w związku z wyrokiem Wojewódzkiego Sądu Administracyjnego w Warszawie z 24 stycznia 2020 r. (sygn. II SA/Wa 1927/19) udostępniła listy poparcia dla kandydatów do KRS. Szerzej zob. Udostępnienie informacji publicznej dot. wykazów sędziów, którzy udzielili poparcia kandydatom do KRS, https://www.sejm.gov.pl/Sejm9.nsf/komunikat.xsp?documentId=F5DF16AFBB3E9E5BC125850E004E5196 (dostęp: 26 III 2020).

Wykazy sędziów, którzy udzielili poparcia kandydatom, są publicznie dostępne: http://www.sejm.gov.pl/sejm9.nsf/page.xsp/krs (dostęp: 26 III 2020). Warto również wspomnieć, że Prezes UODO zaskarżył do NSA wyroki uchylające wstrzymanie ujawnienia list do KRS, https://forsal.pl/amp/1463895, prezes-uodo-zaskarzyl-do-nsa-wyroki-uchylajace-wstrzymanie-ujawnienia-list-do-krs.html (dostęp: 26 III 2020).

${ }^{55}$ Uzasadnienie wyroku SN z 5 XII 2019 r., sygn. III PO 7/18, s. 36.

${ }^{56}$ M. Jałoszewski, Kilku sędziów ujawniło, że ich podpisy są na utajnionych przez PiS listach poparcia członków neo-KRS, 3 VIII 2019, https://oko.press/kilku-sedziow-ujawnilo-ze-ich-podpisy-sa-na-utajnionych-przez-pis-listach-poparcia-czlonkow-neo-krs/ (dostęp: 20 XII 2019). 
z ministrem sprawiedliwości ${ }^{57}$. Koincydencja tych zdarzeń wydaje się nieprzypadkowa, podobnie jak dobór ekspertów promowanych na stronach tego portalu i zaprzyjaźnionych, współdziałających organizacji. To bardzo dobrze, że komuś zależy na edukowaniu społeczeństwa w zakresie określonych powiązań, gdyż - jak słusznie podkreśla R. Wielki - dostęp do informacji publicznej odgrywa istotną rolę w procesie przeciwdziałania korupcji ${ }^{58}$. Dla prowadzonych rozważań istotne znaczenie ma również to, że przed 2015 r. prywatne i publiczne media nie były zainteresowane rozszyfrowywaniem sieci wpływów, powiązań i zależności występujących w środowisku sędziowskim, a także charakteru relacji łączących wybranych przedstawicieli władzy sądowniczej z innymi władzami, korporacjami, organizacjami pozarządowymi, partiami politycznymi itd.

Opinia Ministerstwa Sprawiedliwości na temat interpretacji wyroku TSUE z 19 listopada 2019 r. jest odmienna od prezentowanego stanowiska SN. W ocenie ministra wydane przez TSUE orzeczenie, będące odpowiedzią na pytania prejudycjalne zadane przez Izbę Pracy SN, prowadzi do konkluzji, że „polski Sąd Najwyższy ma badać niezależność nowej Izby Dyscyplinarnej, by ustalić, czy może ona rozpoznawać spory dotyczące przejścia sędziów Sądu Najwyższego w stan spoczynku. Zdaniem TSUE, gdyby Sąd Najwyższy uznał, że Izbie Dyscyplinarnej brak niezależności i bezstronności, mógłby - zgodnie z wyrokiem Trybunału - przestać stosować przepisy, na mocy których to właśnie do Izby Dyscyplinarnej należy rozpoznawanie sporów dotyczących przejścia w stan spoczynku sędziów Sądu Najwyższego" ${ }^{\prime 59}$. Ponadto minister

${ }^{57}$ P. Wachowiec, Powiazania z Ministrem Ziobrą ma 12 z 15 członków neo-KRS. Ujawniamy, 3 XII 2019, https://oko.press/powiazania-z-ministrem-ziobra-ma-12-z-15-czlonkow-neo-krs-ujawniamy/ (dostęp: 20 XII 2019).

Na portalu OKO.press dominuje jednostronny przekaz komunikacyjny i wypowiada się stałe grono jedynie słusznych autorytetów, którym umożliwia się dzielenie wiedzą z opinią publiczną, a także kształtowanie świadomości polskiego społeczeństwa w kierunku myślenia zgodnie z jasną i czytelną domeną przekazu, który wykorzystywany jest do walki politycznej. Szerzej zob. https://oko.press/tag-rzeczowy/sadownictwo/ (dostęp: 20 XII 2019).

${ }^{58}$ R. Wielki, Dostęp do informacji publicznej jako prawne narzędzie zwalczania korupcji. (Glosa do wyroku Naczelnego Sadu Administracyjnego z dnia 3 stycznia 2012 r., sygn. akt: I OSK 2157/11), „Opolskie Studia Administracyjno-Prawne” 2017, nr 3, s. 115-123.

${ }^{59}$ Z. Ziobro o wyroku TSUE: „To wielka porażka nadzwyczajnej kasty. Trybunał orzekł to, czego się spodziewałem", 19 XI 2019, https://tvn24.pl/polska/zbigniew-ziobro-o-wyroku-tsue-trybunal-orzekl-to-czego-sie-spodziewalem-ra986582-2300503 (dostęp: 20 XII 2019). 
sprawiedliwości dodał, że „zgodnie z polską konstytucją, organem, do którego należy ostatnie słowo w sprawie ustrojowej organizacji sądownictwa w Polsce, jest Trybunał Konstytucyjny" ${ }^{\prime 60}$.

Odnosząc się do meritum, tj. do głównej sentencji dokonanego rozstrzygnięcia $w$ wydanym przez SN wyroku z 5 grudnia 2019 r. (co zostało wcześniej szczegółowo opisane), trzeba potwierdzić słuszność tezy, że sporna kwestia dotyczyła przeniesienia konkretnego sędziego NSA w stan spoczynku. A zatem skład orzekający Izby Pracy w istocie rozpoznawał konkretna, problemową sprawę z uwzględnieniem wyroku TSUE. Ta jednoznaczna ocena stanu faktycznego oraz konkluzji podjętej decyzji nie daje się zanegować ani podważyć. Zasadniczy problem polega jednak na tym, że zawarte w uzasadnieniu tezy i argumenty, jakie legły u podstaw wydanego wyroku w indywidualnej (jednostkowej) sprawie, zostały następnie przez sąd wykorzystane do poinformowania opinii publicznej o prawnej interpretacji, która bezpośrednio nawiązuje do innych spornych zagadnień. Stwierdzenia SN wprost odwołują się do szerzej nakreślonych i zdefiniowanych problemów, a mianowicie są m.in. odpowiedzią na pytania: czy Izba Dyscyplinarna SN jest sądem w rozumieniu prawa unijnego i krajowego, co rzutuje na prawomocność wyroków, czy nowa KRS jest organem bezstronnym i niezawisłym, co bezpośrednio wiąże się z kwestią postrzegania i oceny decyzji, jakie podejmowane są przez ten kolegialny organ.

W świetle powyższych przesłanek Ministerstwo Sprawiedliwości uważa, że wyrok TSUE z 19 listopada 2019 r. nie upoważnia polskich sądów i nie daje im podstawy prawnej do tego, aby powołując się na decyzję TSUE, można było podważać legalność wyboru członków KRS i działań podejmowanych przez ten organ, a w szczególności kwestionować status sędziów wskazanych przez nową KRS oraz prawomocność wydawanych przez nich orzeczeń. W werdykcie TSUE w żadnym zdaniu nie stwierdzono, że nowa KRS została wadliwie wybrana i jako organ działa w nienależytym składzie osobowym, a podejmowane kolegialnie decyzje nie mają podstaw prawnych i w związku z tym mogą być unieważnione, Izba Dyscyplinarna SN działa niegodnie z obowiązującym prawem, a nominacje sędziów wchodzących w jej skład są z mocy prawa nieważne, podobnie jak podjęte przez nich decyzje.

Organ, jakim jest KRS, wypowiedział się na temat wyroku TSUE z 19 listopada 2019 r. w swoim stanowisku z 13 grudnia 2019 r.,

${ }^{60}$ Ibidem. 
nawiązując jednocześnie do interpretacji dokonanej przez $\mathrm{SN}$ w wyroku z 5 grudnia 2019 r. Na wstępie zaznaczono, że „udział Krajowej Rady Sądownictwa jako organu opiniodawczego nie może rodzić wątpliwości co do bezstronności sędziego powoływanego na stanowisko przez Prezydenta RP, na co zwrócił również uwagę Trybunał Sprawiedliwości Unii Europejskiej w wyroku z dnia 19 listopada 2019 r. (teza 133)"61. Odwołano się zatem wyłącznie do jednej ze 172 tez, na dodatek prezentując jej treść $w$ zmienionej formie, niż wynika to $z$ oryginalnego zapisu przywołanego fragmentu wyroku TSUE. Przedstawiając dowód uzasadniający wyrażoną refleksję o zniekształceniu, niezbędne jest zacytowanie tezy 133: „w tym względzie i w odniesieniu do samych okoliczności, w jakich doszło do powołania członków Izby Dyscyplinarnej, należy na wstępie sprecyzować, że sam fakt, iż są oni powoływani przez Prezydenta RP, nie może powodować zależności owych członków od tego organu ani budzić wątpliwości co do ich bezstronności, jeżeli po powołaniu osoby te nie podlegają żadnej presji i nie otrzymują zaleceń podczas wykonywania swoich obowiązków"62.

Co ważne, KRS, wyrażając stanowisko w kwestii skutków wyroku SN z 5 grudnia 2019 r., prezentuje następującą argumentację: „zgodnie z art. 87 i 88 ustawy z dnia 8 grudnia 2017 r. o Sądzie Najwyższym (t.j. Dz.U. z 2019 r., poz. 825) rozumianymi a contrario, wyrok ten - jako nie posiadający mocy zasady prawnej - nie wiąże nawet innych składów Sądu Najwyższego, tym bardziej nie może więc wiązać innych sądów i organów Państwa"63. Podano podstawę prawną dla wyrażonej tezy, która jest poprawna merytorycznie i logicznie uzasadniona.

W rezultacie taka opinia KRS może być wykorzystana na kilka sposobów. Po pierwsze, umożliwia składowi orzekającemu innej Izby SN dokonanie biegunowo odmiennej interpretacji wyroku TSUE ${ }^{64}$, a także

${ }^{61}$ Szerzej zob. Stanowisko Krajowej Rady Sądownictwa z dnia 13 grudnia 2019 roku, http://www.krs.pl/pl/aktualnosci/d,2019,12/6115, stanowisko-krajowej-rady-sadownictwa-z-dnia-13-grudnia-2019-r (dostęp: 20 XII 2019).

${ }^{62}$ Szerzej zob. wyrok TSUE w sprawie Izby Dyscyplinarnej i neoKRS (wyrok z uzasadnieniem), 19 XI 2019 r., https://www.iustitia.pl/3412-wyrok-tsue-w-sprawie-izby-dyscyplinarnej-i-neokrs-wyrok-z-uzasadnieniem (dostęp: 20 XII 2019).

${ }^{63}$ Stanowisko Krajowej Rady Sądownictwa z dnia 13 grudnia 2019 roku.

${ }^{64} \mathrm{~W}$ dniu 8 I 2020 r. siedmioosobowy skład Izby Kontroli Nadzwyczajnej i Spraw Publicznych Sądu Najwyższego podjął uchwałę dotyczącą zasad wykonania i konsekwencji prawnych wyroku TSUE z 19 XI 2019 r., której nadano moc zasady prawnej. Syntetycznie rzecz ujmując, uznano, że w uzasadnionym przypadku można unieważnić uchwałę KRS, natomiast prezydenckie nominacje dla sędziów są nie do podważenia. Sędziowie składu orzekającego Izby Kontroli Nadzwyczajnej i Spraw Publicznych podkreślili, że 
daje podstawę do wystąpienia z wnioskiem o usunięcie rozbieżności, jakie występują w orzecznictwie $\mathrm{SN}^{65}$. Po drugie, może stanowić argument dla działań innych organów Państwa, które nie zgadzają się z omawianym wyrokiem SN. Bardzo wyraźne zalecenia i oczekiwania znajdują swoje odzwierciedlenie w następującym zdaniu: „KRS jednoznacznie stwierdza, że wszelkie działania podważające legalność powołania sędziów powinny spotkać się ze stanowczą reakcją uprawnionych do tego organów"66. Bardzo zręcznym i przemyślanym posunięciem jest zatem podjęcie próby zanegowania nie tyle samej legalności powołania sędziów przez prezydenta RP, lecz zakwestionowania roli nowej KRS w procedurze nominacyjnej ze względu na wywieranie negatywnego wpływu na zdolność sądu do niezależnego i bezstronnego realizowania zadań w zakresie wymierzania sprawiedliwości ${ }^{67}$. Logiczne

„Krajowa Rada Sądownictwa jest z mocy Konstytucji RP strukturalnie powiązana ze wszystkimi trzema władzami, jednak nie może to prowadzić do powstawania zależności, które oznaczałyby instrumentalizację KRS celem realizacji partykularnych interesów ze szkodą dla dobra wspólnego". To, czy taka zależność zaistniała, może być przez SN badane "wyłącznie w konkretnym przypadku, przy ocenie legalności uchwał KRS".

Szerzej zob. Uchwała składu 7 sędziów Sądu Najwyższego z 8 I 2020 r., sygn. I NOZP 3/19, http://www.sn.pl/sprawy/SitePages/Zagadnienia_prawne.aspx?Item $\mathrm{SID}=1318-301 \mathrm{f} 4741-66 \mathrm{aa}-4980-\mathrm{b} 9 \mathrm{fa}-873$ e90506a11 \&ListName=Zagadnienia_prawne (dostęp: 15 I 2020).

${ }^{65}$ W dniu 15 I 2020 r. Pierwsza Prezes Sądu Najwyższego, działając na podstawie art. $83 \S 1$ Ustawy z dnia 8 grudnia 2017 r. o Sądzie Najwyższym (tekst jedn. Dz.U. 2019, poz. 825 ze zm.), wystąiła z wnioskiem o usunięcie rozbieżności w wykładni prawa występującej w orzecznictwie Sądu Najwyższego przez skład połączonych Izb Sądu Najwyższego - Izby Cywilnej, Izby Karnej oraz Izby Pracy i Ubezpieczeń Społecznych.

Szerzej zob. Oświadczenie Pierwszego Prezesa SN z 15 I 2020 r., http://www. sn.pl/aktualnosci/SitePages/Wydarzenia.aspx?ItemSID=591-0dc69815-3ade-42fabbb8-549c3c6969c5\&ListName=Wydarzenia (dostęp: 15 I 2020).

${ }^{66} \mathrm{KRS}$ w swoim stanowisku nie precyzuje i nie wyjaśnia, jakie uprawnione organy mają podejmować stosowne działania (postępowania dyscyplinarne bądź postępowania karne), podaje natomiast argumentację prawną przemawiającą na rzecz braku podstaw do kwestionowania statusu sędziów. „Zgodnie z art. 179 Konstytucji RP, powołanie na urząd sędziego należy do wyłącznej kompetencji Prezydenta Rzeczypospolitej, która nie podlega kontroli i jest wolna od wpływu ze strony wszystkich innych organów państwa jak też nie podlega jakiejkolwiek merytorycznej ocenie. W związku z tym, tryb powoływania sędziów, jaki istnieje w polskim systemie prawnym, nie może prowadzić do podważania ich legalnej pozycji w wymiarze sprawiedliwości. Tak też stwierdził Trybunał Konstytucyjny w wyroku z dnia 5 VI 2012 r. sygn. K 18/09" (Stanowisko Krajowej Rady Sądownictwa z dnia 13 grudnia 2019 roku).

${ }^{67}$ Pytanie prawne sformułowane przez Małgorzatę Gersdorf, Pierwszego Prezesa SN: „Czy udział w składzie sądu powszechnego, sądu wojskowego lub Sądu Najwyższego 
rozumowanie, wiedza i doświadczenie życiowe nakazują przypuszczać, że gdyby przewidywalne rozstrzygnięcie składu sędziowskiego trzech Izb SN okazało się trudne do zaakceptowania dla przedstawicieli władzy wykonawczej bądź grona sędziów, to prawdopodobne jest, że zostanie skierowany wniosek o wykładnię interpretacyjną do Trybunału Konstytucyjnego.

W dalszej części komunikatu podano informację, że „niedopuszczalne jest stanowisko Sądu Najwyższego wyrażone w wyroku z dnia 5 grudnia 2019 r. co do tego, że Izba Dyscyplinarna Sądu Najwyższego, której sędziowie zostali pozytywnie zaopiniowani przez Krajową Radę Sądownictwa, nie jest sądem w rozumieniu prawa Unii Europejskiej oraz prawa krajowego" ${ }^{\prime \prime 8}$. Wyjaśniono przy tym, dlaczego takie stwierdzenie jest niezasadne, tj. ze względu na jakie merytoryczne argumenty i przesłanki. Odnosząc się do tez zawartych w wyroku SN z 5 grudnia 2019 r. (sygn. III PO 7/18), KRS wyraża opinię wskazującą na niedopuszczalność konkluzji, że „sędzia powołany przez inny organ niż Krajowa Rada Sądownictwa, w kształcie, w jakim istniała przed 6 marca 2018 r., np. Radę Państwa Polskiej Rzeczypospolitej Ludowej, nie jest legalnie powołanym sędzią i nie może sprawować swojego urzędu, bądź też powinien być pozbawiony stanu spoczynku"69.

Mimo takiego osądu KRS okazało się jednak, że 18 grudnia 2019 r. inny skład orzekający SN wystąił z kolejnymi pytaniami prejudycjalnymi do TSUE, tym razem dotyczącymi ustalenia m.in. na podstawie

osoby powołanej do pełnienia urzędu na stanowisku sędziowskim przez Prezydenta Rzeczypospolitej Polskiej na wniosek Krajowej Rady Sądownictwa, ukształtowanej w trybie określonym przepisami ustawy z dnia 8 grudnia 2017 r. o zmianie ustawy o Krajowej Radzie Sądownictwa oraz niektórych innych ustaw (Dz.U. z 2018 r., poz. 3 ze zm.), prowadzi do naruszenia art. 45 ust. 1 Konstytucji Rzeczypospolitej Polskiej, art. 6 ust. 1 Konwencji o Ochronie Praw Człowieka i Podstawowych Wolności (Dz.U. z 1993 r. Nr 61, poz. 284 ze zm.) lub art. 47 Karty Praw Podstawowych Unii Europejskiej i art. 19 ust. 1 Traktatu o Unii Europejskiej, wskutek czego, zależnie od rodzaju rozpoznawanej sprawy:

a) w postępowaniu karnym - osoba taka jest nieuprawniona do orzekania (art. 439 $\S 1$ pkt 1 k.p.k.) albo zachodzi przypadek nienależytej obsady sądu (art. $439 \S 1$ pkt 2 k.p.k.);

b) w postępowaniu cywilnym - skład sądu z udziałem tak powołanej osoby jest sprzeczny z przepisami prawa (art. 379 pkt 4 k.p.c.)?".

Szerzej zob. wniosek Pierwszego Prezesa Sądu Najwyższego do składu połączonych Izb Cywilnej, Karnej oraz Pracy i Ubezpieczeń Społecznych, BSA I-4110-1/20, Warszawa, 15 I 2020.

${ }^{68}$ Stanowisko Krajowej Rady Sądownictwa z dnia 13 grudnia 2019 roku.

${ }^{69}$ Ibidem. 
przepisów Traktatu o Unii Europejskiej w związku z Kartą Praw Podstawowych Unii Europejskiej, czy w rozumieniu prawa UE jest sądem niezawisłym, bezstronnym i posiadającym odpowiednie kwalifikacje taki organ, w którym zasiada osoba powołana po raz pierwszy lub kolejny (do sądu wyższej instancji) do pełnienia urzędu na stanowisku sędziego przez polityczny organ władzy wykonawczej państwa o totalitarnym, niedemokratycznym, komunistycznym systemie władzy (Radę Państwa PRL) $)^{\prime \prime 70}$. Warto odnotować, że autorem tych interesujących pytań jest sędzia Izby Cywilnej SN ${ }^{71}$ Kamil Zaradkiewicz, rekomendowany na stanowisko sędziowskie przez nową KRS ${ }^{72}$. Wcześniej pracował m.in. jako dyrektor Zespołu Orzecznictwa i Studiów w biurze Trybunału Konstytucyjnego ${ }^{73}$, następnie został powołany na kierownicze stanowisko w Ministerstwie Sprawiedliwości ${ }^{74}$, a potem trafił do rady nadzorczej spółki z udziałem Skarbu Państwa ${ }^{75}$.

Podsumowując dotychczasowe rozważania, trzeba powiedzieć, że występujące odmienne stanowiska, oceny i różnice zdań na temat interpretacji wyroku TSUE są uwarunkowane wieloma czynnikami. Jest ważne, aby zrozumieć, że ich właściwa percepcja wymaga myślenia analitycznego, które ukierunkowane jest na identyfikację sieci powiązań

${ }^{70}$ Szerzej zob. Sąd Najwyższy wystąił do TSUE z pytaniami prejudycjalnymi, 18 XII 2019, http://www.sn.pl/aktualnosci/SitePages/Komunikaty_o_sprawach.aspx?ItemSI$\mathrm{D}=338$-b6b3e804-2752-4c7d-bcb4-7586782a1315\&ListName=Komunikaty_o_sprawach (dostęp: 15 I 2020).

${ }^{71}$ Sędzia Izby Cywilnej udostępnił opinii publicznej na Fecebooku listę sędziów SN nominowanych przez Radę Państwa PRL, powołując się przy tym na orzeczenie TSUE z 19 XI 2019 r., https://prawo.gazetaprawna.pl/artykuly/1446547,sn-zaradkiewicz-lista-sedziow-nominowana-przez-rade-panstwa-prl-tsue.html, 31 XII 2019 r. (dostęp: 15 I 2020).

${ }^{72}$ M. Jałoszyński, Ziobro wygrał z Pawłowicz. Zaradkiewicz będzie w SN, bo zmienit zdanie o definicji matżeństwa, 28 VIII 2018, https://oko.press/ziobro-wygral-z-pawlowicz-zaradkiewicz-bedzie-w-sn-bo-zmienil-zdanie-o-definicji-malzenstwa/ (dostęp: 15 I 2020).

${ }^{73}$ Punktem zwrotnym w karierze sędziego Zaradkiewicza stała się publiczna wypowiedź dla TVP Info, że orzeczenia TK nie zawsze są wiążące, w związku z którą ówczesny Prezes TK Andrzej Rzepliński podjął decyzję o wypowiedzeniu mu dotychczasowej umowy o pracę z przeniesieniem na niższe stanowisko, https://www.tvp. info/26235962/zaradkiewicz-do-upadku-autorytetu-tk-przyczynil-sie-prezes-rzeplinski (dostęp: 15 I 2020).

${ }^{74}$ Dr Kamil Zaradkiewicz dyrektorem w Ministerstwie Sprawiedliwości, https://www.rp.pl/ Prawnicy/304109958-Dr-Kamil-Zaradkiewicz-dyrektorem-w-Ministerstwie-Sprawiedliwosci.html (dostęp: 15 I 2020).

${ }^{75}$ Mówit, że orzeczenia TK nie muszą być wiążace. Teraz trafit do spótki z udziałami Skarbu Państwa?, http://wiadomosci.gazeta.pl/wiadomosci/7,114883,20355235,prawnik-trybunalu-konstytucyjnego-w-radzie-nadzorczej-naftoportu.html (dostęp: 15 I 2020). 
oraz wykreowanych zależności, w kontekście dbania o partykularne interesy, wymierne korzyści, utrzymanie władzy i wpływów jako nadrzędny cel podejmowanych działań i decyzji.

10 grudnia 2019 r. Pierwsza Prezes SN wydała oświadczenie (chętnie propagowane przez media), które zawiera argumenty i sformułowania mające na celu wywarcie wpływu na działalność Izby Dyscyplinarnej:

W ślad za wyrokiem Sądu Najwyższego z dnia 5 listopada 2019 r., III PO 7/18, oraz wyrokiem Trybunału Sprawiedliwości Unii Europejskiej z dnia 19 listopada 2019 r. w połączonych sprawach C-585/18, C-624/18 i C-625/18, wzywam sędziów Izby Dyscyplinarnej do powstrzymania się od wszelkich czynności orzeczniczych w prowadzonych sprawach. [...] kontynuowanie działalności przez Izbę Dyscyplinarną stanowi poważne zagrożenie dla stabilności porządku prawnego w Polsce ${ }^{76}$.

W kolejnym oświadczeniu Pierwszego Prezesa z dnia 17 grudnia 2019 r. zawarto następujące stwierdzenia:

Na sądy nie da się nałożyć kagańca w postaci wyroków Trybunału Konstytucyjnego, które ograniczą instytucję pytań prejudycjalnych, bo jego rozstrzygnięcia nigdy nie mogą sądom państw członkowskich zamykać drogi do Trybunału Sprawiedliwości. Takie rozwiązanie prowadzić będzie wprost do wystąpienia przez Polskę z Unii Europejskiej. Nie będzie więc zgody na to, aby wykładnia Konstytucji, ustaw i traktatów, jaką sędziom wolno stosować, wykuwała się w zaciszu partyjnych gabinetów. Tego nie zmieni ani taka, ani inna ustawa ${ }^{77}$.

Po tym jak siedmioosobowy skład Izby Kontroli Nadzwyczajnej i Spraw Publicznych SN 8 stycznia 2020 r. podjął uchwałę, że wyrok TSUE z 19 listopada 2019 r. powinien być wykonany w pełni z poszanowaniem zasad Konstytucji $\mathbf{R P}^{78}$, zostało opublikowane kolejne

${ }^{76}$ Oświadczenie Pierwszego Prezesa Sądu Najwyższego, PPI-0131-2757/19, Warszawa, 10 XII 2019 r., https://tvn24.pl/wiadomosci-z-kraju,3/malgorzata-gersdorf-wzywa-sedziow-izby-dyscyplinarnej-sn-do-powstrzymania-sie-od-orzekania, $992095 . h t m l$ (dostęp: 20 I 2020).

77 Oświadczenie Pierwszego Prezesa Sądu Najwyższego, PPI-0131-2867/19, Warszawa, dnia 17 grudnia $2019 \mathrm{r}$.

${ }^{78} \mathrm{~W}$ tej uchwale SN potwierdził konstytucyjny zakaz badania skuteczności aktu ustrojowego powołania sędziego przez Prezydenta Rzeczypospolitej Polskiej oraz wynikającego z niego stosunku ustrojowego.

Szerzej zob. Uchwała SN z dnia 8 stycznia 2020 r., podjęta w składzie siedmiu sędziów Izby Kontroli Nadzwyczajnej i Spraw Publicznych (dot. zagadnienia prawnego w sprawie o sygn. I NOZP 3/19), http://www.sn.pl/aktualnosci/SitePages/Komunikaty_o_sprawach.aspx?ItemSID=340-b6b3e804-2752-4c7d-bcb4-7586782a1315\&ListName=Komunikaty_o_sprawach (dostęp: 20 I 2020). 
oświadczenie Pierwszego Prezesa SN z 15 stycznia, w którym poinformowano o wystąpieniu z wnioskiem o usunięcie rozbieżności występującej w orzecznictwie Sądu Najwyższego przez połączony skład trzech $\mathrm{Izb}^{79}$. Dla prawidłowej percepcji uwarunkowań oraz intencji, jakie przyświecają działaniom sędziów SN, nie można pominąć tego, co się wydarzyło w następstwie inicjatywy mającej doprowadzić do jednoznacznego osądu sprawy.

20 stycznia 2020 r. na stronie internetowej SN ukazał się komunikat informujący opinię publiczną (zainteresowanych czytelników), że Prezes kierujący Izbą Dyscyplinarną zwrócił się do Pierwszego Prezesa SN z wnioskiem o wyznaczenie do tego rozstrzygnięcia składu SN uwzględniającego Izbę Dyscyplinarną oraz Izbę Kontroli Nadzwyczajnej $^{80}$. W argumentacji wskazano m.in. na zastrzeżenia w kwestii uznaniowego doboru składu orzekającego i brak bezstronności wyznaczonych sędziów, a prosząc o priorytetowe potraktowanie sprawy, odwołano się do "niepokoju i troski o prawidłowe funkcjonowanie wymiaru sprawiedliwości w Polsce ${ }^{\prime 81}$. Nie można nie zauważyć tego, że wystąpienie Prezesa Izby Dyscyplinarnej ma ścisły związek z wydanym 17 stycznia 2020 r. postanowieniem SN (sygn. BSA I-4110-1/20), w którym stwierdzono, że:

na mocy art. $40 \S 1$ pkt 1 k.p.k. siedmioro sędziów Izby Cywilnej z mocy prawa jest wyłączonych od udziału w rozpoznaniu wniosku Pierwszego Prezesa SN z 15 stycznia 2020 r. sygn. BSA I-4110-1/20, bowiem "rozstrzygnięcie tego wniosku dotyczy tych sędziów bezpośrednio, co stanowi ustawową przesłankę wyłączenia zgodnie z zasadą nemo iudex in causa sua"s2.

Tego samego dnia, tj. 20 stycznia 2020 r., na stronie internetowej ujawniono informacje, że SN udzielił zabezpieczenia z urzędu w związku z wystąpieniem 18 grudnia 2019 r. z pytaniami prejudycjalnymi do

\footnotetext{
${ }^{79}$ Oświadczenie Pierwszego Prezesa Sądu Najwyższego, PPI-0131-174/2020, Warszawa, dnia 15 I $2020 \mathrm{r}$.

${ }^{80}$ Szerzej zob. Komunikat Rzecznika Prasowego Izby Dyscyplinarnej Sądu Najwyższego, 20 I 2020 r., http://www.sn.pl/aktualnosci/SitePages/Wydarzenia.aspx?ItemSID=593-0dc69815-3ade-42fa-bbb8-549c3c6969c5\&ListName=Wydarzenia (dostęp: 20 I 2020).

${ }^{81}$ Ibidem.

${ }^{82}$ Sąd Najwyższy wyłączył siedmiu sędziów Izby Cywilnej od udziału w rozpoznaniu wniosku Pierwszego Prezesa SN z 15 I 2020, Komunikat z 20 I 2020 r. o sprawie BSA I-4110-1/20, http://www.sn.pl/aktualnosci/SitePages/Komunikaty_o_sprawach. aspx?ItemSID=344-b6b3e804-2752-4c7d-bcb4-7586782a1315\&ListName=Komunikaty_o_sprawach (dostęp: 21 I 2020).
} 
TSUE (w sprawie V CSK 347/19) (33 $^{3}$ Ta decyzja została podjęta jednoosobowo przez sędziego Izby Cywilnej, który na mocy wskazanego postanowienia SN z 17 stycznia 2020 r. (wydanego w składzie trzyosobowym), został wyłączony od udziału w rozpoznaniu wniosku Pierwszego Prezesa z 15 stycznia 2020 r., sygn. BSA I-4110-1/20. Poinformowano, że SN w celu zapewnienia tymczasowej ochrony sądowej praw gwarantowanych w porządku prawnym zawiesza, w zakresie wskazanym w pkt II-III, stosowanie:

a) art. 82-84 oraz art. 86 i art. 87 ustawy z dnia 8 grudnia 2017 r. o Sądzie Najwyższym (Dz.U. z 2018 r., poz. 5 ze zm.),

b) odpowiednich znajdujących zastosowanie lub mających być zastosowanymi w postępowaniu przed Sądem Najwyższym albo innym właściwym sądem, także związkowo, przepisów Kodeksu postępowania cywilnego, w tym art. 45, art. 48 , art. 49 , art. 52, art. 189 , art. 379, art. 388, art. 390, art. 395, art. 397, art. 398[15], art. 412-413, art. 424[10], art. 424[11] \& 2 k.p.c. ${ }^{84}$

Krótko rzecz ujmując, to zabezpieczenie w sprawie V CSK 347/19 de facto ma doprowadzić do podważenia podstawy prawnej wniosku Pierwszego Prezesa z 15 stycznia 2020 r., sygn. BSA I-4110-1/20, a mianowicie chodzi o art. 83 \& 1 Ustawy z dnia 8 grudnia 2017 r. o Sądzie Najwyższym, a także art. 379 pkt 4 k.p.c., występującego w spornym zagadnieniu prawnym. Z kolei wysoce znamienny jest fragment tegoż wniosku wyjaśniający, czego dotyczy rozstrzygnięcie TSUE, a także dokonanej interpretacji przez Pierwszego Prezesa:

Jakkolwiek stanowisko TSUE wyrażone w wyroku z dnia 19 listopada $2019 \mathrm{r}$. sformułowano w sprawie dotyczącej statusu Izby Dyscyplinarnej Sądu Najwyższego, to jednak - w ocenie Pierwszego Prezesa Sądu Najwyższego - znaczną część motywów wyroku zajmują rozważania natury ogólnej i uniwersalnej aksjologicznie, które odnoszą się do oceny prawnej aktualnego systemu powoływania sędziów w Rzeczypospolitej Polskiej ${ }^{85}$.

Posiedzenie Sądu Najwyższego w celu rozpoznania powyższego wniosku z 15 stycznia 2020 r., sygn. BSA I-4110-1/20, zostało wyznaczone na 23 stycznia 2020 r., a więc w ekspresowym tempie, tj.

${ }^{83}$ Szerzej zob. SN udzielił zabezpieczenia w związku z wystąpieniem w dniu 18 XII 2019 r. z pytaniami prejudycjalnymi do TSUE, Komunikat z 20 I 2020 r. o sprawie V CSK 347/19, http://www.sn.pl/aktualnosci/SitePages/Komunikaty_o_sprawach.aspx?Item SID=343-b6b3e804-2752-4c7d-bcb4-7586782a1315\&ListName=Komunikaty_o_sprawach (dostęp: 21 I 2020).

${ }^{84}$ Ibidem.

${ }^{85}$ Pismo Pierwszego Prezesa SN, sygn. BSA I-4110-1/20, Warszawa, 15 I 2020, s. 4. 
w ciągu ośmiu dni. Tyle samo czasu upłynęło od wydania uchwały przez Izbę Kontroli Nadzwyczajnej i Spraw Publicznych do wniosku Pierwszego Prezesa o rozstrzygnięcie sporu przez skład orzekający połączonych Izb. Największa akceleracja działalności sądu i podejmowanych inicjatyw miała jednakże miejsce po dniu 17 stycznia. Istotnym zdarzeniem jest decyzja z dnia 21 stycznia 2020 r. (tj. na dwa dni przed zaplanowanym posiedzeniem połączonych trzech Izb), kiedy to Izba Dyscyplinarna wystąiła z wnioskiem do Trybunału Konstytucyjnego z pytaniami prawnymi dotyczącymi wykładni interpretacyjnej art. 439 § 1 pkt 1 i art. 439 \$ 1 pkt 2 Ustawy z dnia 6 czerwca 1997 r. Kodeks postępowania karnego ${ }^{86}$ oraz o wstrzymanie lub zawieszenie postępowania w sprawie wniosku Pierwszego Prezesa SN z 15 stycznia $2020 r^{87}$

Ponadto 22 stycznia 2020 r. Marszałek Sejmu wystąpiła z wnioskiem do TK o „rozstrzygnięcie dwóch sporów kompetencyjnych między: Sejmem a SN oraz Prezydentem RP a SN", który został pozytywnie rozpoznany jeszcze tego samego dnia. $W$ podanym do mediów komunikacie poinformowano o decyzji Prezes TK, że "zgodnie z ustawą wszczęcie postępowania przed TK powoduje zawieszenie postępowań przed organami, które prowadzą spór kompetencyjny"88. Dodatkowo zaznaczono, że pisma procesowe w tej sprawie zostały doręczone wszystkim uczestnikom postępowania, w tym Pierwszej Prezes SN ${ }^{89}$. Informacja o zawieszeniu postępowania przez TK dotarła do SN, co znajduje swoje potwierdzenie w komunikacie Rzecznika Prasowego SN z 22 stycznia. Z jego treści wynika, że posiedzenie SN zaplanowane na 23 stycznia nie zostało odwołane, natomiast w końcowym fragmencie komunikatu podkreślono, że "stosowanie różnych norm prawnych oparte być musi na realnych podstawach, które przynajmniej w istotnym stopniu są uprawdopodobnione ${ }^{\prime \prime 90}$.

${ }^{86}$ Dz.U. 2018, poz. 1987 ze zm.

${ }^{87}$ Szerzej zob. Komunikat w sprawie (II DSI 75/19), 22 I 2020: SN w Izbie Dyscyplinarnej wystąpił do Trybunału Konstytucyjnego z pytaniami prawnymi wraz z wnioskiem o udzielenie zabezpieczenia, http://www.sn.pl/aktualnosci/SitePages/Komunikaty_o_ sprawach.aspx?ItemSID=345-b6b3e804-2752-4c7d-bcb4-7586782a1315\&ListName= Komunikaty_o_sprawach (dostęp: 22 I 2020).

${ }^{88}$ Szerzej zob. Oświadczenie Prezes TK w sprawie wniosku Marszałek Sejmu, https:// fakty.interia.pl/polska/news-jest-oswiadczenie-prezes-tk-w-sprawie-wniosku-marszalek-ejm,nId,4283312 (dostęp: 22 I 2020).

${ }^{89}$ Ibidem.

${ }^{90}$ Szerzej zob. Komunikat Rzecznika Prasowego SN, 22 I 2020, http://www.sn.pl/ aktualnosci/SitePages/Wydarzenia.aspx?ItemSID=595-0dc69815-3ade-42fa-bbb8549c3c6969c5\&ListName=Wydarzenia (dostęp: 22 I 2020). 
Analizując wnikliwie przedstawione fakty, a także istotne okoliczności mające zasadniczy wpływ na przebieg opisywanych działań, daje się dostrzec wiele niepodważalnych argumentów i dowodów na intencjonalne wykorzystywanie władzy sędziowskiej dla określonych potrzeb i celów. Ponadto przeprowadzone badania stanowią ugruntowaną podstawę dla wyartykułowania następujących konkluzji i jednoznacznych twierdzeń:

- stosowanie dowolności interpretacyjnej wyroku TSUE prowadzi do sytuacji, w której podejmowane są biegunowo odmienne, kolidujące i sprzeczne ze sobą rozstrzygnięcia oraz autorytatywne decyzje procesowe, zależnie od tego, jaki skład orzekający SN wypowiada się na dany temat, co powoduje chaos i destabilizację systemu prawnego;

- jeśli to samo problemowe zagadnienie i te same przepisy obowiązującego w Polsce prawa można eksplikować na wiele różnych sposobów w zależności od tego, w jakim składzie osobowym sądu podejmowane są decyzje i rozstrzygnięcia, to oznacza, że sędziowie w sprawowaniu swojej władzy mogą być ewidentnie stronniczy i działać woluntarystycznie, nie ponosząc jednocześnie żadnej odpowiedzialności za swoje czyny;

- przedstawiciele aparatu sądowniczego mogą wykorzystywać sprawowaną władzę i zajmowaną pozycję zawodową w sposób koniunkturalny, dbając jednocześnie o ochronę korzyści, przywilejów, a także partykularnych interesów, mających istotne znaczenie dla jednej ze stron toczącego się sporu, w którym biorą udział „prominentne elity sędziowskie" podejmujące działania w celu zakwestionowania wprowadzanych reform, zablokowania ich dalszego etapu oraz nowi sędziowie, którzy są beneficjentami dokonywanych zmian;

- trudno jest doszukiwać się bezstronności, poczucia sprawiedliwości i poszanowania dla zasad prawa, jeśli ta sama sprawa może być dowolnie interpretowana przez różne składy orzekające, co musi budzić uzasadnione obawy i niepokój obywateli, którzy kiedyś mieli okazję empirycznie tego doświadczyć na własnym przykładzie, stąd też obecna sytuacja znacząco podważa zaufanie obywateli nie tylko do SN, osłabiając autorytet i majestat naczelnego organu władzy sądowniczej, ale w szerszym kontekście bardzo negatywnie rzutuje na postrzeganie i wiarygodność całego systemu sądownictwa w Polsce;

- wyroki sądowe są wydawane w imieniu Rzeczypospolitej Polskiej, dlatego też używa się określenia, że rozstrzygnięcia dokonał sąd (wyrok, 
orzeczenie, postanowienie sądu), tymczasem o meritum każdej decyzji de facto przesądza dobór konkretnego składu osobowego, który został wyznaczony do rozpoznania danej sprawy, natomiast poszczególni sędziowie biorący w tym udział nie ponoszą osobistej odpowiedzialności za podejmowane działania, gdyż emanacją sprawowania władzy jest sąd jako organ procesowy;

- jeśli okazuje się, że zasadniczy wpływ na werdykt ma powołany skład osobowy sądu i swoboda interpretacyjna, to niezawisłość sędziowska ujęta w art. 178 ust. 1 Konstytucji RP: „[s]ędziowie w sprawowaniu swojego urzędu są niezawiśli i podlegają tylko Konstytucji oraz ustawom" w praktyce oznacza to, że jedynym i zarazem wystarczającym uzasadnieniem dla motywów, jakie legły u podstaw wszystkich arbitralnych decyzji, a także poczynań związanych z wykonywaniem funkcji orzeczniczej, jest powołanie się na treść art. 178, co zamyka dyskusje w przedmiotowym zakresie;

- opisana wcześniej chronologia zdarzeń oraz koincydencja określonych decyzji i procesów muszą skłaniać do wniosku, że strony biorące udział w tej konfrontacji potrafią z góry przewidzieć, jakie rozstrzygnięcia i czynności zostaną podjęte przez oponentów, co wymusza konieczność podejmowania reaktywnych działań.

Można było przypuszczać, że dla rozpatrywanego problemu będzie miało znaczenie rozstrzygnięcie TK w sprawie dotyczącej dopuszczalności wniosku o wyłączenie sędziego z powodu okoliczności wadliwości powołania sędziego przez Prezydenta RP na wniosek KRS zaplanowane na 13 lutego $2020 \mathrm{r} .{ }^{91}$ Istnieje pewna szansa na to, że przyczyni się to do uporządkowania systemu prawnego, $\mathrm{z}$ całą pewnością natomiast nie zakończy dyskusji na temat jednolitości orzecznictwa ${ }^{92}$, praworządności, niezależności sądownictwa, konieczności zwracania się przez sądy krajowe z pytaniami prejudycjalnymi ${ }^{93}$, bezpośredniego stosowania

${ }^{91}$ Wniosek o wyłączenie sędziego z powodu podniesienia okoliczności wadliwości powołania sędziego przez Prezydenta RP na wniosek Krajowej Rady Sądownictwa (sygn. P 22/19), http://trybunal.gov.pl/postepowanie-i-orzeczenia/wokanda/art/10924-wniosek-o-wylaczenie-sedziego-z-powodu-podniesienia-okolicznosci-wadliwosci-powolania-sedziego-przez-prezydenta-rp-na-wniosek-krajowej-rady-sadownictwa (dostęp: 22 I 2020).

${ }_{92}$ T. Grzybowski, Jednolitość orzecznictwa a paradygmat interpretacyjny (ze szczególnym uwzglednieniem reguty clara non sunt interpretanda, "Archiwum Filozofii Prawa i Filozofii Społecznej" 2013, nr 2, s. 25-37.

${ }^{93} \mathrm{M}$. Taborowski, Mechanizmy ochrony praworządności państw członkowskich w prawie Unii Europejskiej. Studium przebudzenia systemu ponadnarodowego, Warszawa 2019, s. 15-16. 
Konstytucji ${ }^{94}$, niezależności KRS i niezawisłości sędziów ${ }^{95}$, a także odpowiedzialności dyscyplinarnej sędziów ${ }^{96}$.

Wypowiadając się na temat odpowiedzialności sędziów, należy koniecznie zaznaczyć, że kwestia ta jest ściśle powiązana z możliwością dokonywania arbitralnej i wysoce uznaniowej interpretacji przepisów prawa przy rozpoznawaniu konkretnej sprawy. Jak słusznie podkreśla P. Skuczyński, „mając na względzie owo «niezbywalne prawo sędziego» do własnej, samodzielnej interpretacji prawa, trzeba też dostrzec, że łączy się z tym nierozerwalnie ryzyko sądowej pomyłki, wadliwości w interpretacji prawa czy nawet rażącego błędu w procesie wykładni" ${ }^{\prime \prime 7}$. Te przesłanki nie dają jednak podstawy do tego, aby sędzia podlegał osobistej odpowiedzialności za podejmowane działania, o czym warto pamiętać. A zatem „środkiem korygowania ewentualnych błędów czy pomyłek orzeczniczych są przewidziane przez przepisy prawa procesowego środki kontroli instancyjnej" ${ }^{\prime \prime 8}$. Powołanie się na bezpośrednie stosowanie Konstytucji nie zawsze będzie wyłączać odpowiedzialność dyscyplinarną sędziego. Dotyczy to w szczególności takich sytuacji, kiedy możliwe jest postawienie sędziemu zarzutu sprzeniewierzenia się zasadzie niezawisłości lub braku bezstronności ${ }^{99}$. Można polemizować

${ }^{94}$ A. Chmielarz-Grochal, Bezpośrednie stosowanie art. 45 ust. 1 Konstytucji Rzeczypospolitej Polskiej, "Przegląd Prawa Konstytucyjnego" 2016, nr 3, s. 67-101.

${ }^{95}$ M. Niezgódka-Medek, Krajowa Rada Sąownictwa jako gwarant niezależności sądów i niezawisłości sędziów do czasu wprowadzenia zmian na przełomie 2017 i 2018 r., w: Konstytucja. Praworządność. Władza sądownicza. Aktualne problemy trzeciej władzy w Polsce, pod red. Ł. Bojarskiego, K. Gajewskiego, J. Kremera, G. Ott, W. Żurka, Warszawa 2019, s. 93-106; A. Rakowska-Trela, Krajowa Rada Sądownictwa po wejściu w życie nowelizacji z 8.12.2017 r. organ nadal konstytucyjny czy pozakonstytucyjny?, w: Konstytucja. Praworzadność. Wtadza sądownicza..., s. 107-122.

${ }^{96}$ D. Skrzypiński, Odpowiedzialność sędziów w świetle zjawiska judykalizacji polityki, "Wrocławskie Studia Politologiczne" 2014, nr 17, s. 53-64; P. Mazur, Uwagi o odpowiedzialności dyscyplinarnej sędziów za rażąca i oczywistą obraze prawa w polskim systemie prawnym, "Ethics in Progress" 2017, t. 8, nr 2, s. 97-109; P. Skuczyński, Nierepresyjne funkcje odpowiedzialności dyscyplinarnej a model postępowania w sprawach dyscyplinarnych, "Przegląd Legislacyjny" 2017, nr 3, s. 35-53.

${ }^{97}$ P. Skuczyński, Bezpośrednie stosowanie Konstytucji RP przez sądy a odpowiedzialność dyscyplinarna sędziów, „Kwartalnik o Prawach Człowieka” 2017, nr 3-4, s. 89.

${ }^{98}$ W uchwale z 11 X 2002 r. Sąd Najwyższy, odmawiając zgody na pociągnięcie sędziego SN do odpowiedzialności karnej za tzw. zbrodnie komunistyczne, stwierdził, że „Wiążąca się nierozerwalnie z konstytucyjną zasadą niezawisłości sędziowskiej zasada jurysdykcyjnej samodzielności sądu zakłada zarówno samodzielność sądu w ustalaniu faktów sprawy, jak i samodzielność w wykładni prawa, oraz samodzielność w rozstrzyganiu na podstawie ustalonych faktów i dokonanej wykładni" (ibidem).

${ }^{99}$ Ibidem, s. 95. 
z tezą A. Chmielarz-Grochal, że wszystkie organy władzy publicznej, w tym sądy, mają "konstytucyjny obowiązek bezpośredniego stosowania przepisów konstytucyjnych", co wprost wynika z art. 8 ust. 2 i zasady nadrzędności Konstytucji wyrażonej w art. 8 ust. $1^{100}$. Godzi się zauważyć, że organy władzy wykonawczej i ustawodawczej, a także sądowniczej zgodnie $z$ art. 7 ustawy zasadniczej są zobowiązane do działania oraz podejmowania decyzji na podstawie prawa i w granicach prawa, a zatem jedynie sędziowie mogą powiedzieć na temat sprawowania swojego urzędu, że w stosowaniu prawa "podlegają tylko Konstytucji i ustawom".

W literaturze przedmiotu akcentuje się pogląd, że wartości konstytucyjne winny być uwzględniane w procesie stanowienia i stosowania prawa ${ }^{101}$. Podkreśla się przy tym, że "sąd konstytucyjny jako interpretator konstytucji ma bardzo duży zakres swobody, a niekiedy musi podjać decyzje autorytatywnie kończące spór, co do treści określonych pojęćc $c^{\prime 102}$. Przy ustalaniu znaczenia tych zastanych pojęć Trybunał Konstytucyjny pełni funkcję niemal ustrojodawczą ${ }^{103}$. Pojawiają się też takie opinie, że "globalną ekspansję władzy sędziowskiej uznaje się za signum temporis współczesnych przemian w procesie rządzenia. Zdeponowanie ogromnej władzy w rękach sędziów konstytucyjnych rodzi pytanie, czy taką formułę można, a jeśli tak, to na jakich zasadach, pogodzić z zasadami demokracji"104. Z zacytowanych twierdzeń jasno wynika, że to Trybunał jest sądem mającym przyznane uprawnienia w zakresie dokonywania ostatecznej i wiążącej wykładni przepisów Konstytucji RP. Można oczywiście podejmować naukowe rozważania na temat separacji władz ${ }^{105}$, pozycji ustrojowej sądownictwa ${ }^{106}$, Konstytucji i konstytucjonalizmu ${ }^{107}$, natomiast nie daje się zakwestionować, że to Konstytucja stanowi

${ }^{100}$ A. Chmielarz-Grochal, op. cit., s. 68.

${ }^{101}$ M. Kondej, Przełamanie rezultatów wykładni językowej zgodnie z zasadą nadrzędności Konstytucji, „Ruch Prawniczy, Ekonomiczny i Socjologiczny” 2019, z. 3, s. 40.

${ }^{102}$ R. Piotrowski, Pojęcia zastane w Konstytucji RP. Dylematy teorii i praktyki, w: Źródła prawa. Teoria i praktyka, pod red. T. Giary, Warszawa 2016, s. 22.

${ }^{103}$ Ibidem.

${ }^{104}$ K. Kaleta, Sąownictwo konstytucyjne w warunkach ponowoczesności, w: Teoria prawa. Między nowoczesnościa a ponowoczesnościa, pod red. A. Samonek, Kraków 2013, s. 21.

${ }^{105}$ P. Tuleja, Division of Power and the Problem of Excessive Concentration of Power in the Light of the Polish Constitution, "Przegląd Konstytucyjny” 2018, nr 4, s. 59-75.

${ }^{106}$ K. Grajewski, Założenia i rzeczywistość władzy sądowniczej - uwagi w dwudziesta rocznice wejścia w życie Konstytucji III RP, „Przegląd Konstytucyjny” 2018, nr 1, s. 37-64.

${ }^{107}$ D. Minich, Konstytucja - konstytucjonalizm - neokonstytucjonalizm, „Przegląd Prawa Publicznego" 2018, nr 12, s. 68-75. 
fundament porządku państwowego i jest źródłem legitymizacji władzy państwa ${ }^{108}$. Czynniki kształtujące prawo, jakie w największym stopniu oddziałują na wykorzystywanie władzy w praktyce, bardzo celnie identyfikuje J. Zajadło, używając określenia „magiczny trójkąt: prawodawcy, sędziowie, profesorowie"109, a J. Majchrowski słusznie dodaje, że na podejmowane działania silny wpływ wywiera polityka ${ }^{110}$.

\section{Interpretacja prawna dotycząca sędziów wybranych przez nową KRS - uchwała składu połączonych trzech Izb SN z 23 stycznia 2020 r. w opinii Ministerstwa Sprawiedliwości}

Część przedstawicieli środowiska prawniczego ${ }^{111} \mathrm{~W}$ ostatnich latach zwraca uwagę na działania będące przejawem naruszania praworządności i wartości konstytucyjnych, w tym m.in. „zasady demokratycznego państwa prawa, trójpodziału władzy, niezależności sądów i niezawisłości sędziów"1112. Krytykowanie wprowadzanych reform, a także kwestionowanie legalności działań/decyzji podejmowanych przez nową KRS (określaną w publicznym dyskursie przez ekspertów i prominentnych sędziów mianem neo-KRS), uległo nasileniu po wyroku TSUE z 19 listopada 2019 r., co było do przewidzenia.

D. Łukowiak, komentując wyrok TK z 25 marca 2019 r., podkreśla, że z przepisów Konstytucji wprost wynika, kto jest wybierany do KRS, natomiast $\mathrm{w}$ ustawie zasadniczej nie określono, przez kogo i w jaki sposób mają być wybierani sędziowie wchodzący w skład tego organu. Biorąc pod uwage powyższe, autor wyjaśnia, że według TK „nic nie stoi na przeszkodzie, aby sędziów do KRS wybierali sędziowie. Jednak nie można się zgodzić z twierdzeniem, że piastunem czynnego prawa wyborczego muszą tu być wyłącznie gremia sędziowskie"113. W dalszej

${ }^{108}$ D. Minich, Konstytucja oraz konstytucjonalizm w dobie ponowoczesnej, w: Teoria prawa..., s. 35 .

${ }^{109}$ J. Zajadło, Magiczny trójkąt: prawodawcy, sędziowie, profesorowie, w: Konstytucja. Praworządność. Władza sądownicza..., s. 65-90.

${ }_{110}$ J. Majchrowski, Źródła prawa a praktyka polityczna, w: Źródła prawa..., s. 51-65.

111 http://monitorkonstytucyjny.eu/archiwa/category/publicystyka/komentarze-i-opinie/page/2 (dostęp: 25 I 2019)

112 A. Rakowska-Trela, Sądy i sędziowie wobec niedemokratycznych przemian, "Studia Politologiczne" 2018, t. 47, s. 300.

${ }^{113}$ D. Łukowiak, Glosa do wyroku Trybunału Konstytucyjnego z 25 marca 2019 r., sygn. akt K 12/18 (wybór sędziów do składu Krajowej Rady Sądownictwa przez Sejm), „Przegląd Konstytucyjny" 2019, nr 3, s. 102. 
części prowadzonego wywodu wyraża odmienny pogląd: „zgodnie z przyjętymi zasadami wykładni tekstu prawnego, luka konstrukcyjna w postaci braku literalnego wskazania w art. 187 ust. 1 pkt 2 Konstytucji podmiotu, który wybiera sędziów członków KRS, powinna zostać uzupełniona poprzez zastosowanie systemowych i funkcjonalnych dyrektyw wykładni, nie zaś poprzez domniemanie kompetencji Sej$\mathrm{mu}^{\prime \prime 114}$. Jest to zatem autonomiczna opinia stanowiąca głos w dyskusji, stwierdzenia te nie mają zaś mocy prawnej i nie są wiążące. Jeśli uznać, że takie domniemanie kompetencji parlamentu jest w państwie prawa niedopuszczalne w świetle zasady legalizmu (art. 7 Konstytucji) ${ }^{115}$, to na podstawie tego samego przepisu można również sformułować podobne zastrzeżenia pod adresem innych organów, rywalizujących o władzę w Polsce ${ }^{116}$. Dotyczy to w szczególności tych organów władzy sądowniczej, które próbują uzurpować sobie kompetencje/uprawnienia decyzyjne w zakresie oceniania konstytucyjności wybranych aktów prawnych, zważywszy na fakt, że każdy organ władzy publicznej - nie wyłączając Sejmu - może działać tylko na podstawie i w granicach prawa oraz $\mathrm{w}$ formach przez to prawo przewidzianych. Jak widać, dla interpretacji prawa w określonym celu zawsze można się posłużyć odpowiednimi argumentami, które będą uzasadniały przyjęty tok rozumowania. Nie zmienia to jednak faktu, że głoszone tezy pozostają jedynie w sferze wyrażanych poglądów, opinii, które nie wywołują skutków prawnych.

Inaczej jest w przypadku uchwały składu połączonych Izb: Cywilnej, Karnej oraz Pracy i Ubezpieczeń Społecznych SN, podjętej 23 stycznia 2020 r. ${ }^{117}$ Mówiąc w dużym skrócie, treść tej uchwały - zważywszy na wszystkie analizowane okoliczności sprawy i motywy działania - stanowi odzwierciedlenie realizacji zamierzonego celu. Używając prostych i zrozumiałych objaśnień, jej sentencja sprowadza się do tego, że SN, a precyzyjnie rzecz ujmując, sędziowie głosujący za przyjęciem omawianej Uchwały nie zaprzeczają temu, iż sędziowie wybrani przez nową KRS są legalnie powołani przez Prezydenta RP na swoje urzędy sędziowskie, podważane natomiast są ich kompetencje orzecznicze (nie

${ }^{114}$ Ibidem, s. 106.

${ }^{115}$ Ibidem.

${ }^{116}$ D. Minich, Veto players jako koncepcja rywalizacji o władzę pomiędzy organami władzy państwowej, "Przegląd Prawa Publicznego” 2018, nr 7-8, s. 43-53.

117 Szerzej zob. Uchwała składu połączonych Izb: Cywilnej, Karnej oraz Pracy i Ubezpieczeń Społecznych Sądu Najwyższego z 23 I 2020 r., http://www.sn.pl/ aktualnosci/SitePages/Wydarzenia.aspx?ItemSID=598-0dc69815-3ade-42fa-bbb8549c3c6969c5\&ListName=Wydarzenia (dostęp: 23 I 2020). 
mają uprawnień do orzekania). Według treści uchwały SN nienależyta obsada sądu zachodzi także wtedy, gdy w składzie sądu bierze udział osoba powołana na urząd sędziego na wniosek nowej KRS ${ }^{118}$.

Jest to ewidentny przykład argumentum ad absurdum ${ }^{119}$, ponieważ z logicznego i prawnego punktu widzenia status sędziego należy interpretować następująco: sędzią jest osoba powołana na urząd sędziego i mająca (posiadająca z tego tytułu) prawo rozstrzygania spraw oraz wymierzania sprawiedliwości. $Z$ faktu bycia powołanym na urząd sędziego jednoznacznie wynika to, że dana osoba ma status sędziego. A zatem jeśli nie podważa się legalności powołania sędziego przez Prezydenta, to oznacza, że absolutnie niedopuszczalne jest kwestionowanie uprawnień, tj. praw takiego sędziego do wykonywania funkcji orzeczniczych w składzie sędziowskim danego sądu. Godzi się w tym miejscu zauważyć, że konkluzja podjętej uchwały sprowadza się do tego, że sędziowie wybrani przez nową KRS nie są uprawnieni do wykonywania czynności orzeczniczych, co w konsekwencji ma prowadzić do „zawieszenia ich w urzędowaniu". Podejmowanie wiążących prawnie decyzji w kwestii odsunięcia danego sędziego od orzekania (co de facto sprowadza się do zawieszenia w sprawowaniu urzędu) nie może nastąpić w wyniku uchwały SN dotyczącej usunięcia rozbieżności w orzecznictwie, tj. dokonującej wykładni interpretacyjnej wybranych przepisów. Takie działania i czynności prawne są rażąco sprzeczne z Konstytucją, gdyż zgodnie z art. 180 ust. 2 "Złożenie sędziego z urzędu, zawieszenie $\mathrm{w}$ urzędowaniu, przeniesienie do innej siedziby lub na inne stanowisko wbrew jego woli może nastąpić jedynie na mocy orzeczenia sądu i tylko w przypadkach określonych w ustawie".

W trosce o dobro wspólne, interes publiczny i zapewnienie poczucia bezpieczeństwa prawnego obywateli sąd zdecydował, że „wykładnia art. 439 § 1 pkt 2 k.p.k. oraz art. 379 pkt 4 k.p.c. przyjęta w punktach 1 i 2 niniejszej uchwały nie ma zastosowania do orzeczeń wydanych przez sądy przed dniem jej podjęcia oraz do orzeczeń, które zostaną wydane $\mathrm{w}$ toczących się $\mathrm{w}$ tym dniu postępowaniach na podstawie Kodeksu postępowania karnego przed danym składem sądu ${ }^{120}$. Taka interpretacja ma uniemożliwić podnoszenie wadliwości dotychczas wydanych

\footnotetext{
118 Ibidem.

${ }^{119}$ M. Matczak, Argumentum ad absurdum w uzasadnieniu decyzji stosowania prawa a założenie o racjonalności prawodawcy - analiza krytyczna, w: Uzasadnienia stosowania pra$w a$, pod red. I. Rzucidło-Grochowskiej, M. Grochowskiego, Warszawa 2015, s. 102-115. ${ }^{120}$ Ibidem.
} 
wyroków przez składy orzekające z udziałem sędziów wskazanych do objęcia swoich urzędów przez nową KRS. Ten przepis uchwały jest bezpośrednio skierowany do obywateli, którzy mają być wdzięczni SN za to, że rozpoznane dotąd przez sądy sprawy nie będą mogły być z tej przyczyny podważane.

W odmienny sposób SN (w wydanej uchwale) odniósł się do problemu bezpieczeństwa w zakresie ochrony praw i przywilejów, jakie przysługują wąskiej grupie obywateli mających postępowania przed Izbą Dyscyplinarną. W tym przypadku uznano, że nienależyta obsada sądu w rozumieniu art. $439 \S 1$ pkt 2 k.p.k. albo sprzeczność składu sądu z przepisami prawa w rozumieniu art. 379 pkt 4 k.p.c. zachodzi także wtedy, gdy w składzie sądu bierze udział osoba powołana na urząd sędziego SN na wniosek nowej KRS. Ten punkt uchwały "ma zastosowanie do orzeczeń wydanych z udziałem sędziów Izby Dyscyplinarnej utworzonej w Sądzie Najwyższym na podstawie ustawy z dnia 8 grudnia 2017 r. o Sądzie Najwyższym (Dz.U. z 2018 r., poz. 5 ze zm.) bez względu na datę wydania tych orzeczeń" ${ }^{\prime 21}$.

W ocenie Ministerstwa Sprawiedliwości "Uchwała SN z dnia 23.01.2020 r. z mocy prawa jest nieważna. Została wydana z rażącym naruszeniem prawa. Narusza art. 179, art. 180 ust. 1 oraz art. 10 Konstytucji RP. [...] Uchwała składu trzech izb Sądu Najwyższego jako niezgodna z prawem nie wywołuje skutków prawnych. Ponadto po wejściu w życie ustawy z 20 grudnia 2019 roku gwarantującej konstytucyjny porządek w wymiarze sprawiedliwości i usprawniającej pracę sądów, uchwała SN tym bardziej stanie się bezprzedmiotowa"122.

Niestety, oficjalne stanowisko Ministerstwa (zgodnie z tym, co podano w tytule) jest zwykłym oświadczeniem, tj. zawiera wyrażone poglądy interpretacyjne i opinie, które nie są wiążące dla polskich sądów. Mogą być jedynie potraktowane jako skierowany do opinii publicznej "głos w toczącej się dyskusji" na temat funkcjonowania wymiaru sprawiedliwości (jak miało to miejsce wcześniej). Co ważne, uchwała trzech Izb SN jest bezpośrednio adresowana do sędziów, którzy otrzymali oczekiwane rozstrzygnięcie rozbieżności w wykładni prawa występującej w orzecznictwie Sądu Najwyższego, tj. zasady prawnej wiążącej inne składy orzekające SN, która ma być stosowana przez inne sądy w Polsce.

${ }^{121}$ Ibidem.

122 Szerzej zob. Oświadczenie w sprawie uchwały Sądu Najwyższego, 23 I 2020, https://www.gov.pl/web/sprawiedliwosc/oswiadczenie-w-sprawie-uchwaly-sadu-najwyzszego (dostęp: 23 I 2020). 
Doceniając rangę i doniosłość analizowanej uchwały SN, a także jednoznaczne stanowisko Ministerstwa Sprawiedliwości ${ }^{123}$, nie można jednak powiedzieć, że w dniu 23 stycznia doszło do przełomowego unormowania konstytucyjnego porządku prawnego, zapewnienia praworządności oraz ustabilizowania konfliktowej sytuacji w polskim wymiarze sprawiedliwości. Wręcz odwrotnie, dopiero teraz może się potęgować chaos, który - zgodnie z przewidywaniami - spowoduje konieczność zaangażowania $\mathrm{TK}^{124}$ do rozstrzygnięcia spornych kwestii ${ }^{125}$. Trzeba bowiem potrafić właściwie zrozumieć perfekcyjnie przemyślany plan związany nie tylko z treścią, lecz przede wszystkim z celowością podjęcia takiej uchwały. Dzięki tej decyzji grupa kontestatorów reformy zyskuje bardzo doniosły argument: czytelny, prosty i wymowny w odczuciu społecznym ${ }^{126}$. Krytykowanie rozstrzygnięcia, w którym brało udział grono wybitnych oraz doświadczonych sześćdziesięciu sędziów

${ }^{123}$ Według opinii Ministerstwa Sprawiedliwości „Żaden organ, także sądowy, nie może bowiem kwestionować powołania i inwestytury sędziego" (w teorii prawa), tymczasem w praktyce stosowania prawa sześćdziesięciu sędziów SN w ramach czynności orzeczniczych usuwa rozbieżności wykładni prawa występujące w orzecznictwie Sądu.

${ }^{124}$ Szerzej zob. sprawy rozpatrywane przez Trybunał Konstytucyjny: Status Izby Dyscyplinarnej Sądu Najwyższego jako sądu (P 3/20), Art. 439 par. 1 pkt 2 kpk, art. 379 pkt 4 kpc oraz art. 83 par. 1 ustawy o Sądzie Najwyższym w odniesieniu do oceny niezależności Krajowej Rady Sadownictwa oraz procedury poprzedzającej powołanie sędziego przez Prezydenta RP na wniosek KRS (K 5/20), Art. 379 pkt 4 kpc i art. 439 \$ 1 pkt 1 kpk w odniesieniu do procedury powołania sędziego przez Prezydenta RP na wniosek Krajowej Rady Sadownictwa ukształtowanej w trybie określonym przepisami ustawy z dnia 8.12.2017 r. (K 3/20), Art. 379 pkt 4 kpc, art. 439 par. 1 pkt 2 kpk oraz art. 83 par. 1 ustawy o Sadzie Najwyższym w odniesieniu do oceny niezależności Krajowej Rady Sądownictwa oraz procedury poprzedzającej powołanie sędziego przez Prezydenta RP na wniosek KRS (K 2/20), Spór kompetencyjny między Sejmem RP a Sądem Najwyższym oraz między Prezydentem RP a Sądem Najwyższym (Kpt 1/20), https://trybunal. gov.pl/sprawy-w-trybunale (dostęp: 26 III 2020).

Duże znaczenie z punktu rozpatrywanego problemu ma najnowsza informacja, że TSUE stwierdził niedopuszczalność pytań prejudycjalnych polskich sędziów, 26 III 2020, https://www.gov.pl/web/sprawiedliwosc/tsue-stwierdzil-niedopuszczalnosc-pytan-prejudycjalnych-polskich-sedziow (dostęp: 26 III 2020).

${ }^{125}$ Można sądzić, że największe znaczenie będzie miało rozstrzygnięcie TK zaplanowane na 31 III 2020 r. (termin rozprawy przełożono na 15 IV 2020 r.) - sprawa U 2/20, Uchwała składu połaczonych Izb: Cywilnej, Karnej oraz Pracy i Ubezpieczeń Społecznych Sąu Najwyższego z dnia 23 stycznia 2020 r., sygn. akt BSA I 4110 1/20, https://trybunal.gov.pl/postepowanie-i-orzeczenia/wokanda/art/10986-uchwala-skladu-polaczonych-izb-cywilnej-karnej-oraz-pracy-i-ubezpieczen-spolecznych-sadu-najwyzszego-z-dnia-23-stycznia-2020-r-sygn-akt-bsa-i-4110-120 (dostęp: 26 III 2020).

${ }^{126}$ Podobnie jak w przypadku używanych określeń: ustawa represyjna, kagańcowa, naruszająca konstytucję (według Sądu Najwyższego) vs. ustawa gwarantująca konstytucyjny porządek, usprawniająca pracę sądów (w ocenie Ministerstwa Sprawiedliwości). 
SN, będzie przedstawiane jako atak niedouczonych jednostek na sędziowską niezawisłość za bezstronną i merytoryczną decyzję ${ }^{127}$, która nie spełnia oczekiwań, bo nie jest po myśli rządzących.

\section{Rozstrzygnięcie TK z 20 kwietnia 2020 r. w sprawie uchwały składu połączonych trzech Izb SN z 23 stycznia 2020 r.}

Analizując dokumenty w przedmiotowej sprawie U 2/20, daje się wyraźnie zauważyć rozbieżność stanowisk w kwestii interpretacji wybranych przepisów prawa, a także odmienność argumentacji prezentowanej przez strony postępowania przed Trybunałem. Odnosząc się w syntetycznym ujęciu do nakreślonego zagadnienia, można powiedzieć, że najważniejsze oceny i konkluzje zawierają się w następujących twierdzeniach. Zdaniem Premiera Rządu (tj. wnioskodawcy) „treść przedmiotowej uchwały składu połączonych trzech Izb SN z 23.01.2020 r. (sygn. BSA 141101/20), mimo zewnętrznej formy, wykazuje cechy charakterystyczne dla przepisów prawa, wydawanych przez centralne organy państwowe w rozumieniu art. 188 pkt 3 Konstytucji $\mathrm{RP}^{\prime \prime 28}$. Konsekwencją takiego toku rozumowania jest opinia, że „zaskarżony akt prawny skutkuje wprowadzeniem do polskiego porządku prawnego trzech zasadniczych nowości normatywnych, wzajemnie ze sobac powiązanych"129. Podano przy tym argumentację, że uchwała składu połączonych Izb SN z 23 stycznia 2020 r. jest niezgodna ze wskazanymi we wniosku przepisami prawa, ponieważ:

- przyznaje sądom powszechnym, wojskowym i Sądowi Najwyższemu nieznaną innym aktom prawnym kompetencję do badania prawidłowości powołania sędziego przez Prezydenta Rzeczypospolitej Polskiej oraz badania prawidłowości procedury poprzedzającej realizację wskazanej prerogatywy;

${ }^{127}$ Zestawiane liczby będą przemawiały do wyobraźni odbiorców: uchwałę poparło sześćdziesięciu doświadczonych sędziów SN z najwyższymi kwalifikacjami, podczas gdy inne zdanie ma minister sprawiedliwości wspierany przez swoich najbliższych politycznych współpracowników. To kto się lepiej zna na prawie i ma rację w tym sporze?

${ }^{128}$ Wniosek Prezesa Rady Ministrów do Trybunału Konstytucyjnego o zbadanie zgodności uchwały połączonych Izb: Cywilnej, Karnej oraz Pracy i Ubezpieczeń Społecznych Sądu Najwyższego z Konstytucją Rzeczypospolitej Polskiej ratyfikowanymi umowami międzynarodowymi i ustawami, Warszawa, 24 II 2020, s. 2.

${ }^{129}$ Ibidem, s. 3. 
- wprowadza do polskiego systemu prawnego nową instytucję, określoną mianem sędziego w stanie spoczynku ab initio, który w myśl zaskarżonego aktu prawnego nie ma możliwości orzekania;

- wprowadza do systemu prawnego reguły intertemporalne, różnicując konsekwencje nowo ustanowionych przepisów dla orzeczeń wydawanych przez sądy, w których składach udział bierze sędzia w stanie spoczynku ab initio ${ }^{130}$.

Zdanie Pierwszego Prezesa Sądu Najwyższego jest biegunowo odmienne, o czym dobitnie świadczy bardzo dosadny, wyrazisty i emocjonalny fragment stanowiska przesłanego do TK, w szczególności na temat rozumienia art. 45 Konstytucji, co zostało poddane szerszej analizie komparatywnej w części drugiej artykułu.

Wniosek Prezesa Rady Ministrów zmierza do legitymizacji bezprawia konstytucyjnego. Trybunał Konstytucyjny orzeka w sprawach zgodności z Konstytucja, co oznacza, że celem jego działania jest ochrona postanowień Konstytucji, nie zaś legitymizacja ich ignorowania. W świetle prawa polskiego i europejskiego niedopuszczalne jest - co wykazano w uchwale połączonych Izb SN - przeprowadzenie zamachu na prawo do sądu, a tak należałoby ocenić zmiany normatywne i faktyczne ostatnich lat w obrębie szeroko rozumianego wymiaru sprawiedliwości i sądownictwa, poczynając od destabilizacji Trybunału Konstytucyjnego i jego podporządkowania większości parlamentarnej, co sprawiło, że Trybunał ten utracił możliwość rzetelnego wykonywania funkcji powierzonych mu przez ustrojodawcę $e^{131}$.

Nie ulega wątpliwości, że cytowana opinia trafnie odzwierciedla charakter wzajemnych relacji i nastawienia wybranych przedstawicieli wymiaru sprawiedliwości względem innych reprezentantów władzy sądowniczej oraz wykonawczej, co ma istotne znaczenie z punktu widzenia prowadzonych rozważań oraz analiz. W dalszej części podano dodatkową argumentację odnoszącą się do kwestii prawnych dotyczących braku kompetencji Trybunału Konstytucyjnego do orzekania w sprawie uchwały połączonych Izb SN:

- nieuprawniona jest teza, jakoby uchwała Sądu Najwyższego mająca moc zasady prawnej tworzyła normy generalne i abstrakcyjne;

- Trybunał Konstytucyjny nie ma kompetencji do weryfikowania orzeczeń sądowych, w tym uchwał wykładniczych Sądu Najwyższego, kształtujących linię orzeczniczą - kognicja Trybunału nie obejmuje

${ }^{130}$ Ibidem, s. 4.

131 Pismo Pierwszego Prezesa Sądu Najwyższego do Trybunału Konstytucyjnego, PP I-0131-1159/20 (sygn. U 2/20), Warszawa, 26 III 2020, s. 3. 
orzeczeń sądowych, bądź też innych rozstrzygnięć organów stosujących prawo;

- uchwała połączonych Izb Sądu Najwyższego jest de facto aktem wykonywania konstytucyjnych kompetencji Sądu Najwyższego w zakresie nadzoru judykacyjnego, który nie może być przedmiotem kontroli sprawowanej przez Trybunał Konstytucyjny, gdyż oznaczałoby to, wbrew przepisom Konstytucji RP, przyznanie Trybunałowi prawa do sprawowania nadzoru nad nadzorem judykacyjnym;

- stan związania wykładnią interpretacyjna, jaka została dokonana w uchwale podjętej przez Sąd Najwyższy w składzie połączonych trzech Izb, odnosi się jedynie do składów orzekających Sądu Najwyższego, a sądy powszechne nie są związane tą uchwała, natomiast respektowanie wyrażonego poglądu wynika wyłącznie z autorytetu Sądu Najwyższego;

- skład orzekający Sądu Najwyższego nie może rozstrzygnąć konkretnej sprawy w sposób sprzeczny z interpretacją zawartą w uchwale połączonych Izb SN, mającą moc zasady prawnej;

- związanie składów orzekających ma charakter względny, możliwe jest bowiem zainicjowanie procedury zmierzającej do uchwalenia rozstrzygnięcia w przedmiocie odstąpienia od poglądu prawnego mającego moc zasady prawnej ${ }^{132}$.

Rzecznik Praw Obywatelskich w podobnym tonie wypowiada się na temat wniosku szefa polskiego rządu, który w ocenie Rzecznika „prowadzi do podważenia ustrojowej roli Sądu Najwyższego, stanowiąc próbę pozbawienia go kluczowego instrumentu ujednolicania orzecznictwa sądowego, służącego ochronie spójności i integralności krajowego systemu prawnego"133. W dalszej części tego stanowiska zawarto następującą opinię: "jest przykładem instrumentalizacji prawa motywowanej względami pozaprawnymi i - w kontekście także innych działań podejmowanych przez organy władzy wykonawczej i ustawodawczej względem władzy sądowniczej - zmierza do sformułowania przez Trybunał Konstytucyjny zakazu, adresowanego do Sądu Najwyższego, podejmowania działań mających na celu zapewnienie spójności i jednolitości wykładni przepisów prawa"134.

Prawidłowo użyty zwrot dotyczący „instrumentalizacji prawa” dla realizacji określonych zamierzeń (celów, interesów, jak również korzyści),

${ }^{132}$ Ibidem, s. 5-11.

${ }_{133}$ Pismo Rzecznika Praw Obywatelskich do Trybunału Konstytucyjnego VII.510.48.2020 (sygn. U 2/20), Warszawa, 24 III 2020, s. 3.

${ }^{134}$ Ibidem, s. 3-4. 
ma jednak o wiele szerszy kontekst i wydźwięk semantyczny, może bowiem odnosić się też do innych przedsięwzięć, a także decyzji podejmowanych przez reprezentantów władzy publicznej, w tym sądowniczej.

Prokurator Generalny (będący jednocześnie Ministrem Sprawiedliwości, członkiem KRS i posłem na Sejm RP) wyraża w piśmie do TK krytyczne opinie prawne na temat przedmiotowej uchwały połączonych Izb SN, a dodatkowo wskazuje następujące przesłanki:

- uzasadnienie uchwały Sądu Najwyższego zawiera liczne oceny natury politycznej, podważające przyjęty przez ustawodawcę model demokratycznego wyłaniania składu Krajowej Rady Sądownictwa, a opowiada się za modelem korporacyjnym, w którym sędziowie wybierają sędziów do KRS;

- forma uzasadnienia uchwały SN polemizuje z wyrokiem Trybunału Konstytucyjnego z 25 marca 2019 r., sygn. K 12/18 (OTK ZU A/2019, poz. 17), a także z wcześniejszym wyrokiem TK z 20 czerwca 2017 r., sygn. K 5/17 (OTK ZU A/2017, poz. 48) i tłumaczy motywy faktycznej odmowy wykonania wskazanych orzeczeń, rażąco naruszającej art. 180 ust. 1 Konstytucji;

- treść uzasadnienia uchwały SN, kwestionując stan prawny poprzedzający jej wydanie, stanowi dodatkowy argument za tym, że zakwestionowany akt prawny SN jest aktem normatywnym, zmieniającym regulację prawną (przepisy prawa) obowiązującą w Rzeczypospolitej Polskiej ${ }^{135}$.

Można zatem powiedzieć, że istota sporu na gruncie prawa sprowadza się do rozstrzygnięcia kilku kwestii: czy rozpatrywana uchwała połączonych Izb SN - ze względu na jej treść (mimo zewnętrznej formy) - może być traktowana i utożsamiana z przepisami prawa wydawanymi przez centralne organy państwowe w rozumieniu art. 188 pkt 3 Konstytucji RP, czy kreuje ona nowe normy prawne bądź też wyłącznie rozstrzyga powstałe w orzecznictwie sądowym rozbieżności w wykładni przepisów powszechnie obowiązującego prawa, a także czy Sąd Najwyższy może podejmować działania o charakterze prawotwórczym, należące do wyłącznej kompetencji organu prawodawczego. Oczywiście każda zainteresowana strona prezentuje własną interpretację, jak również argumenty uzasadniające nie tylko przyjęty tok rozumowania, lecz przede wszystkim rzeczywiste intencje i cele, jakie przyświecają podejmowanym działaniom.

${ }^{135}$ Pismo Prokuratora Generalnego do Trybunału Konstytucyjnego PK VIII TK 33.2020 (sygn. U 2/20), Warszawa, 24 III 2020, s. 4. 
Trybunał Konstytucyjny 20 kwietnia 2020 r., orzekając w pełnym składzie, dokonał wiążącego i ostatecznego rozstrzygnięcia sprawy o sygn. U 2/20 większością głosów ${ }^{136}$, uznając że:

Uchwała składu połączonych Izb: Cywilnej, Karnej oraz Pracy i Ubezpieczeń Społecznych Sądu Najwyższego z dnia 23 stycznia 2020 r. (sygn. akt BSA I 4110 1/20, OSNKW nr 2/2020, poz. 7) jest niezgodna z:

a) art. 179 , art. 144 ust. 3 pkt 17 , art. 183 ust. 1, art. 45 ust. 1, art. 8 ust. 1, art. 7 i art. 2 Konstytucji Rzeczypospolitej Polskiej,

b) art. 2 i art. 4 ust. 3 Traktatu o Unii Europejskiej (Dz.U. z 2004 r. Nr 90, poz. $864 / 30$, ze zm.),

c) art. 6 ust. 1 Konwencji o ochronie praw człowieka i podstawowych wolności, sporządzonej w Rzymie dnia 4 listopada 1950 r., zmienionej następnie Protokołami nr 3, 5 i 8 oraz uzupełnionej Protokołem nr 2 (Dz.U. z 1993 r. $\mathrm{Nr} 61$, poz. 284 , ze zm. $)^{137}$.

Można zatem powiedzieć, że ta decyzja TK (podzielająca pogląd wnioskodawcy) stanowi element porządkujący trwające spory prawne odnośnie do statusu sędziów powołanych przez prezydenta spośród kandydatów wyłonionych przez nową KRS, w skład której wchodzą sędziowie wybrani przez Sejm. Z pewnością nie zakończy ona dyskusji na temat zasad praworządności oraz zmian w polskim wymiarze sprawiedliwości, meritum toczącego się konfliktu dotyczy bowiem walki o władzę, wpływy i kontrolę nad systemem wymiaru sprawiedliwości oraz sędziowskimi kadrami. Zasadniczą rolę odgrywają uprawnienia decyzyjne kształtujące możliwość obejmowania sędziowskich urzędów, awansów, powoływania na kierownicze stanowiska, a także kontroli nad odpowiedzialnością dyscyplinarną. Media aktywnie wpierające kontestatorów przeprowadzanych reform będą oczywiście umniejszały rangę tego wyroku TK poprzez zniekształcanie kontekstu, a także podważanie wiarygodności i zaufania do instytucji w następującej formie: „Trybunał Przyłębskiej o SN: Wykonanie wyroku europejskiego trybunału jest niezgodne z prawem UE"138. Wymaga podkreślenia, że nigdy

${ }^{136}$ Orzeczenie zapadło większością dwunastu głosów, a trzech sędziów zgłosiło zdania odrębne.

${ }^{137}$ Wyrok TK z 20 IV 2020 r., sygn. U 2/20, https://trybunal.gov.pl/postepowanie-i-orzeczenia/wyroki/art/11040-uchwala-skladu-polaczonych-izb-cywilnej-karnejoraz-pracy-i-ubezpieczen-spolecznych-sadu-najwyzszego-z-dnia-23-stycznia-2020-rsygn-akt-bsa-i-4110-120 (dostęp: 20 IV 2020).

${ }^{138}$ D. Sitnicka, Trybunat Przyłębskiej o SN: Wykonanie wyroku europejskiego trybunału jest niezgodne z prawem UE, 20 IV 2020, https://oko.press/trybunal-przylebskiej-o-sn/ (dostęp: 20 IV 2020). 
wcześniej na portalu Oko.press nie użyto podobnego nazewnictwa dla określenia tego konstytucyjnego organu za czasów poprzedniego prezesa, a także w odniesieniu do Sądu Najwyższego, co dobitnie świadczy o nastawieniu do określonych faktów.

Ostatnie wydarzenia potwierdzają słuszność wyrażonej predykcji, gdyż obecnie najnowszy konflikt w sądownictwie dotyczy praktycznej realizacji postanowienia TSUE z 8 kwietnia 2020 r. w sprawie C-791/19 R (Komisja Europejska versus Rzeczpospolita Polska), zobowiązującego Rzeczpospolitą Polską do natychmiastowego zawieszenia stosowania przepisów ustawy o Sądzie Najwyższym stanowiących podstawę właściwości Izby Dyscyplinarnej Sądu Najwyższego w sprawach dyscyplinarnych sędziów. Pierwsza Prezes SN dzień po ogłoszeniu postanowienia TSUE (tj. 9 kwietnia 2020 r.) wydała oświadczenie, że w celu wykonania tegoż postanowienia wzywa:

- „wszystkie osoby powołane na stanowisko sędziego Sądu Najwyższego w Izbie Dyscyplinarnej do natychmiastowego powstrzymania się od jakichkolwiek czynności związanych z rozpoznawaniem spraw określonych w art. 27 ustawy z dnia 8 grudnia 2017 r. o Sądzie Najwyższym (Dz.U. z 2019 r., poz. 825)";

- „pracowników Sądu Najwyższego zatrudnionych w Izbie Dyscyplinarnej do przekazania wszystkich akt spraw, w tym także zakończonych, do Izby Sądu Najwyższego właściwej w związku z zaprzestaniem stosowania art. 27 ustawy z dnia 8 grudnia 2017 r. o Sądzie Najwyższym"139.

Podjęte działania w ramach tej formuły wywierania wpływu na sędziów i pracowników Izby Dyscyplinarnej SN w ocenie Pierwszej Prezes "są niezbędne nie tylko dla zapewnienia ochrony praw uczestników postępowań sądowych, ale także dla powstrzymania pogłębiającego się chaosu prawnego w Polsce oraz zapobieżenia ewentualnemu nałożeniu na Polskę okresowych kar pieniężnych"140. Prezes Izby Dyscyplinarnej SN w wydanym 10 kwietnia 2020 r. komunikacie medialnym zwraca uwagę na fakt, że:

- "Zakres przedmiotowy postanowienia TSUE jest jedynie wąskim fragmentem działalności orzeczniczej Izby Dyscyplinarnej Sądu Najwyższego, do której właściwości zgodnie z wolą ustawodawcy należy

${ }^{139}$ Oświadczenie Pierwszego Prezesa SN z 9 IV 2020 r. w związku z postanowieniem Trybunału Sprawiedliwości Unii Europejskiej z 8 IV 2020 r., http://www. sn.pl/aktualnosci/SitePages/Wydarzenia.aspx?ItemSID=622-0dc69815-3ade42fa-bbb8-549c3c6969c5\&ListName=Wydarzenia (dostęp: 20 IV 2020).

${ }^{140}$ Ibidem. 
także rozpatrywanie spraw dyscyplinarnych prokuratorów, adwokatów, radców prawnych, notariuszy, komorników oraz prowadzenie spraw w przedmiocie zezwolenia na pociągnięcie do odpowiedzialności karnej lub tymczasowe aresztowanie sędziów, asesorów sądowych, prokuratorów i asesorów prokuratury. Izba Dyscyplinarna Sądu Najwyższego zajmuje się także sprawami z zakresu prawa pracy i ubezpieczeń społecznych sędziów Sądu Najwyższego i kwestią przejścia ich w stan spoczynku";

- „Brak jest podstaw do dokonywania rozszerzającej wykładni postanowienia TSUE w przedmiocie zastosowania środków tymczasowych, które wprost w punkcie pierwszym odnosi się do "art. 3 pkt 5, art. 27 i art. $73 \S 1$ ustawy z dnia 8 grudnia 2017 r. o Sądzie Najwyższym (Dz.U. z 2018 r., poz. 5), ze zmianami, stanowiących podstawę właściwości Izby Dyscyplinarnej Sądu Najwyższego zarówno w pierwszej, jak i w drugiej instancji, w sprawach dyscyplinarnych sędziów";

- „Normatywną podstawą działalności Izby Dyscyplinarnej Sądu Najwyższego jest art. 27 ustawy z dnia 8 grudnia 2017 r. o Sądzie Najwyższym. Norma ta nie została przez żaden uprawniony do tego organ władzy publicznej zmieniona lub uchylona. Postanowienie TSUE $\mathrm{z}$ dnia 8 kwietnia 2020 roku nie powoduje $\mathbf{z}$ mocy prawa zawieszenia obowiązywania spornych przepisów, a ewentualną decyzję w tym przedmiocie podejmują odpowiednie, uprawnione do tego w państwie prawa, organy. Wynika to z sentencji postanowienia, która wskazuje, że to Rzeczpospolita Polska zobowiązana jest do jego wykonania";

- "fundamentalnym obowiązkiem każdego sędziego jest sprawowanie wymiaru sprawiedliwości na podstawie i w granicach prawa, co wynika z zasady legalizmu i treści roty ślubowania"141.

Ponadto w wydanym oświadczeniu poinformowano, że 9 kwietnia 2020 r. skierowano pytanie prawne do Trybunału Konstytucyjnego dotyczące oceny zgodności z Konstytucją RP przepisów Traktatu o Unii Europejskiej oraz Traktatu o funkcjonowaniu Unii Europejskiej w zakresie zobowiązania państwa członkowskiego przez TSUE do wykonania środków tymczasowych w sprawach dotyczących ustroju i funkcjonowania konstytucyjnych organów władzy sądowniczej ${ }^{142}$.

${ }^{141}$ Oświadczenie Prezesa Sądu Najwyższego kierującego pracą Izby Dyscyplinarnej SN z 10 IV 2020, http://www.sn.pl/aktualnosci/SitePages/Wydarzenia.aspx?Item $\mathrm{SID}=625-0 \mathrm{dc69815}-3 \mathrm{ade}-42 \mathrm{fa}-\mathrm{bbb} 8-549 \mathrm{c} 3 \mathrm{c} 6969 \mathrm{c} 5 \&$ ListName=Wydarzenia (dostęp: 20 IV 2020).

142 Ibidem. 
Okazało się, że 20 kwietnia 2020 r. (a więc tego samego dnia, w którym zapadł wyrok TK w sprawie uchwały połączonych Izb SN) Pierwsza Prezes SN wydała zarządzenie nr 48/2020. Podstawę prawną dla wydanego dokumentu stanowi art. 14 § 1 Ustawy z dnia 8 grudnia 2017 r. o Sądzie Najwyższym ${ }^{143}$ oraz kierowanie się treścią uchwały składu połączonych Izb: Cywilnej, Karnej oraz Pracy i Ubezpieczeń Społecznych z 23 stycznia 2020 r., w zakresie, w jakim uchwała ta rzutuje na możliwość rozpoznawania określonych spraw przez Izbę Dyscyplinarną SN. W analizowanym dokumencie zawarte są stwierdzenia o zawieszeniu z dniem 8 kwietnia 2020 r. praw Izby Dyscyplinarnej w zakresie przyjmowania oraz rozpoznawania spraw należących do właściwości tej Izby, zawieszenia wykonywania przez Prezesa kierującego praca Izby Dyscyplinarnej kompetencji w zakresie wyznaczania właściwego sądu dyscyplinarnego, z mocy wydanego w tym dniu postanowienia TSUE o zastosowaniu środków tymczasowych w sprawie C-791/19144.

Te przytoczone i udokumentowane fakty jednoznacznie wskazują na całkowitą rozbieżność interpretacyjna, odmienne przesłanki prawne oraz argumenty podawane w oświadczeniach, a jednocześnie stanowiące motywy dla decyzji podejmowanych przez Pierwszego Prezesa SN i Prezesa SN kierującego pracami Izby Dyscyplinarnej. Jest to dowód potwierdzający relatywizm ocen i dowolność stosowania prawa dla realizacji określonych celów i potrzeb. Takie działania są możliwe dzięki posiadanej władzy ze względu na zajmowanie stanowisk (pełnienie funkcji), co ma ścisły związek z przyznaniem danej osobie uprawnień, kompetencji decyzyjnych do wykorzystywania przepisów prawa w praktyce zarządzania. Po zakończeniu kadencji Pierwszego Prezesa SN, sędzia, który został przez Prezydenta RP wyznaczony do pełnienia obowiązków na tym stanowisku, 5 maja 2020 r. wydał zarządzenie nr 55/2020 uchylające wcześniejsze zarządzenie z dnia 20 kwietnia 2020 r. Podano następującą podstawę prawną: art. 14 § 1 w zw. $z$ art. $111 \S 4$ oraz art. 111a w zw. $z$ art. 13a Ustawy z dnia 8 grudnia 2017 r. o Sądzie Najwyższym ${ }^{145}$. Zdecydowano jednocześnie, że prze-

${ }^{143}$ Dz.U. 2019, poz. 825 ze zm.

${ }^{144}$ Szerzej zob. Zarządzenie Pierwszego Prezesa SN z dnia 20 IV 2020 r. dotyczące Izby Dyscyplinarnej, http://www.sn.pl/aktualnosci/SitePages/Wydarzenia.aspx?Item SID=628-0dc69815-3ade-42fa-bbb8-549c3c6969c5\&ListName=Wydarzenia (dostęp: 20 IV 2020).

${ }^{145}$ Zarządzenie Pierwszego Prezesa SN nr 55/2020 z dnia 5 V 2020 r. o wykonaniu postanowienia TSUE z 8 IV 2020 r. o zastosowaniu środków tymczasowych w sprawie C-791/19 oraz o uchyleniu zarządzenia z dnia 20 IV 2020 r., http://www.sn.pl/aktualnosci/SitePages/ 
kazywanie nowych spraw dotyczących postępowań dyscyplinarnych sędziów należących do właściwości Izby Dyscyplinarnej SN zostaje wstrzymane do czasu utraty mocy postanowienia TSUE lub wydania orzeczenia przez Trybunał Konstytucyjny w sprawie o sygn. P 7/20.

\section{Podsumowanie}

Przeprowadzona analiza oraz poczynione rozważania upoważniają do konstatacji, że niektóre opisywane fakty, zdarzenia, podejmowane decyzje, a także inicjowane procesy mogą stanowić egzemplifikację wzorców postępowania, jakie są charakterystyczne dla czynów określanych mianem legalnej korupcji. Biorąc pod uwagę rzeczywiste intencje i zamierzenia stron (zorganizowanych grup) zaangażowanych w te przedsięwzięcia, owe praktyki są świadomie zaplanowanym scenariuszem uzgodnionych i zaakceptowanych do realizacji jawnych (formalnych) działań, umożliwiających intencjonalne wykorzystywanie posiadanej władzy dla ochrony partykularnych interesów, a także materializacji określonych celów. W szerokim ujęciu znaczeniowym to właśnie tzw. legalna korupcja, przejawiająca się w naruszaniu podstawowych praw jednostki ${ }^{146}$, w tym zasady równego traktowania przez władze publiczne, dokonuje prawdziwej segregacji obywateli na dwie kategorie: grupę uprzywilejowanych beneficjentów, mających zapewnione prawo do godnej pracy, zajmowania stanowisk, awansów, akceleracji rozwoju zawodowego, ścieżek kariery, przywilejów, ponadprzeciętnych apanaży itd., oraz ludzi skutecznie marginalizowanych, wykluczanych i blokowanych, tj. obywateli gorszej kategorii, którym takie prawa w praktyce nie przysługują.

E. Maciejewska za pośrednictwem specjalnej strony internetowej ${ }^{147}$ dzieli się cennymi przemyśleniami, które pozwalają bliżej poznać nastroje socjety sędziów. Autorka uważa, że „zabieg dyskredytowania i usuwania dotychczasowych elit wcale nie służy obywatelom. Służy stworzeniu nowej elity, która będzie wdzięczna, całkowicie zależna

\footnotetext{
Wydarzenia.aspx?ItemSID=643=0-d69815c3-ade42-fa-bb8b549-3c6969c5c\&ListNameWydarzenia (dostęp: 5 V 2020).

146 A. Peters, Corruption as a Violation of International Human Rights, „European Journal of International Law" 2018, vol. 29, iss. 4, s. 1251-1287.

${ }^{147}$ Strona informacyjna sędziów Okręgu Łódzkiego, http://sedziowielodzcy.pl/ (dostęp: 23 I 2020).
} 
i bezwzględnie posłuszna władzy, która ją wykreowała"148. Należy się zgodzić z wnioskiem, że obsada eksponowanych funkcji stanowi dominujący i najważniejszy jak dotąd efekt przeprowadzanych reform, co dla zwykłych obywateli faktycznie nie ma najmniejszego znaczenia. Daje się jednak przy tym bardzo wyraźnie dostrzec totalną walkę pomiędzy starymi i nowymi elitami sędziowskimi o utrzymanie wpływów, przywilejów, kumulowanie władzy, budowanie sieci powiązań, wzajemnych interesów, umacnianie wykreowanych zależności itd. To właśnie w głównej mierze do tego sprowadza się istota sporu o przestrzeganie Konstytucji, łamanie zasad demokratycznego państwa, praworządność i tzw. niezależność sędziowską. Oczywiście w komunikatach kierowanych do opinii publicznej świadomie używa się emocjonalnych sformułowań, odnoszących się do zamachu stanu, a nawet stanu wojennego, co dobitnie świadczy o intencjach takich odezw do obywateli: „Stan wojenny w sądownictwie nie jest potrzebny, w sądownictwie jest konieczny Okrągły Stół. Dlatego, Szanowni Obywatele, nie dajcie się zmanipulować i brońcie niezależnych sądów"149.

Ludzie obserwujący z uwagą bieżące wydarzenia mogą się poczuć zdezorientowani sprzecznymi informacjami, jakie docierają do społeczeństwa na temat wielokrotnego naruszenia konstytucji, działań będących przejawem rażącego nadużycia prawa, a także innych przykładów nadużycia władzy przez funkcjonariuszy publicznych ${ }^{150}$, za które nikt nie ponosi odpowiedzialności. Wypada żałować, że taka sytuacja znacząco podważa zaufanie do państwa i jego organów, jeśli bowiem zwykły obywatel przekracza swoje uprawnienia lub podejmuje działania niezgodne/sprzeczne $\mathrm{z}$ prawem, to ponosi z tego tytułu daleko idące konsekwencje (gdyż każdy ma obowiązek przestrzegania prawa Rzeczypospolitej Polskiej, co wynika z art. 83 Konstytucji). Pogłębiona analiza nakreślonego problemu uwzględniająca rozważania na temat istoty legalnej korupcji z pewnością będzie mieć cenne walory edukacyjne nie tylko dla prawników ${ }^{151}$.

148 Szerzej zob. E. Maciejewska, Stan wojenny w sądownictwie, 15 XII 2019, http:// www.sedziowie.nazwa.pl/nucleus/index.php?itemid=160\#more (dostęp: 23 I 2020).

${ }^{149}$ Ibidem.

${ }^{150}$ W. Walczak, Nadużycie władzy publicznej elementem korupcji - próba szerszego ujęcia zjawiska, „Kontrola Państwowa” 2019, nr 3, s. 109-125.

${ }^{151}$ J. Jabłońska-Bońca, Trzeba inaczej uczyć. Kilka uwag o homo zappiens i miękkich umiejętnościach komunikacyjnych prawników, „Krytyka Prawa” 2018, nr 2, s. 373-394. 


\section{INSTRUMENTAL USE OF JUDICIAL POWER AFTER THE JUDGMENT OF THE TSUE - MULTIDIMENSIONAL ANALYSIS OF LEGAL CORRUPTION}

\section{S u m m a ry}

The article presents considerations and multifaceted analyses of the conditions and motives of judicial decisions taken after the judgment of the TSUE 19 November 2019, in the context of how Poland's judiciary system functions. It begins by explaining how to perceive and understand the essence of legal corruption in terms of the use of law, power and professional position. The possibilities of the intentional use of judicial power for specific needs and purposes is discussed in this context.

The next part of the paper is devoted to a critical analysis of selectively interpreted right to a tribunal enshrined in art. 45 of the Polish Constitution in connection with other values enshrined therein. The right of every citizen to a fair and public hearing of their case, without undue delay by a competent, independent, impartial and independent court, is presented in terms of the constitutional perspective, the principle of equal treatment and non-discrimination. The problem outlined here is considered from the point of view of protection against the arbitrariness of authorities and the possibility of appealing against personnel decisions enabling employment to be taken up in selected positions in state institutions. Attention is paid to the privileged legal position of judges over other citizens. The issues described and the arguments presented in this article are entirely overlooked in the literature, as well as in public debate.

What follows is an explanation of how TSUE rulings are interpreted differently by various public authorities. Reference is also made to the dictum of the Supreme Court judgment of 5 December 2019, which was issued in its Labour Law and Social Security Chamber. That process initiated specific actions and activities taken by individual groups of Supreme Court judges. Finally, the resolution of the combined three chambers of the Supreme Court on 23 January 2020, the judgment of the Constitutional Tribunal of 20 April 2020, and divergent decisions regarding the implementation of the TSUE's position of 8 April 2020 are discussed.

Keywords: judicial authority - Polish Constitution - legal corruption - internal security - social justice

\section{LITERATURA}

Chmielarz-Grochal A., Bezpośrednie stosowanie art. 45 ust. 1 Konstytucji Rzeczypospolitej Polskiej, "Przegląd Prawa Konstytucyjnego” 2016, nr 3, s. 67-101.

Duraj N., Przestępstwa nadużycia władzy i korupcji w prawie karnym Federacji Rosyjskiej, "Przegląd Policyjny" 2019, nr 2, s. 42-57.

Fazekas M., Toth I.J., From Corruption to State Capture: A New Analytical Framework with Empirical Applications from Hungary, "Political Research Quarterly" 2016, vol. 69 , iss. 2, s. 320-334. 
Florczak-Wątor M., Prawo do sądu jako prawo jednostki i jako gwarancja horyzontalnego działania praw i wolności, „Przegląd Prawa Konstytucyjnego”, 2016, nr 3, s. $47-66$.

Gieroń K., Prawo do sądu w orzecznictwie Trybunału Konstytucyjnego i orzecznictwie sądowym, w: "Rodzinna Europa". Europejska myśl polityczno-prawna u progu XXI wieku, pod red. P. Fitkusa, H. Malewskiego, M. Marszała, Wrocław 2015, s. 555-571.

Grajewski K., Założenia i rzeczywistość władzy sądowniczej - uwagi w dwudziesta rocznice wejścia w życie Konstytucji III RP, „Przegląd Konstytucyjny” 2018, nr 1, s. 37-64.

Grzybowski T., Jednolitość orzecznictwa a paradygmat interpretacyjny (ze szczególnym uwzglednieniem reguty clara non sunt interpretanda, "Archiwum Filozofii Prawa i Filozofii Społecznej" 2013, nr 2, s. 25-37.

Hałub-Kowalczyk O., Jabłoński M., Radajewski M., Identyfikacja treści prawa do sądu wybrane zagadnienia, Wrocław 2019.

Informacja o działalności Rzecznika Praw Obywatelskich w obszarze równego traktowania za rok 2018 oraz o przestrzeganiu zasady równego traktowania w Rzeczypospolitej Polskiej, 25 XI 2019.

Jabłońska-Bońca J., Trzeba inaczej uczyć. Kilka uwag o homo zappiens i miękkich umiejętnościach komunikacyjnych prawników, „Krytyka Prawa” 2018, nr 2, s. 373-394.

Jabłoński P., O deskryptywnym poziomie interpretacji tekstu prawnego, „Studia Prawno-Ekonomiczne" 2018, nr 106, s. 29-53.

Jabłoński P., Pichlak M., Miejsce refleksji krytycznej w instytucjonalnej wiedzy o prawie, „Principia” 2013, nr 57-58, s. 269-295.

Jaworska M., Prawo do sądu, w: Realizacja i ochrona konstytucyjnych wolności i praw w polskim porzadku prawnym, pod red. M. Jabłońskiego, Wrocław 2014, s. 127152.

Kaleta K., Sąownictwo konstytucyjne w warunkach ponowoczesności, w: Teoria prawa. Między nowoczesnościq a ponowoczesnością, pod red. A. Samonek, Kraków 2013, s. 21-29.

Kiciński K., "Sygnalista” w państwie prawa - spojrzenie z perspektywy socjologii moralności, w: Skarżypyty, donosiciele, sygnaliści? Studium socjologiczno-prawne, pod red. J. Arcimowicz, M. Bieńko, B. Łaciak, Warszawa 2018, s. 231-245.

Kondej M., Przełamanie rezultatów wykładni językowej zgodnie z zasadą nadrzędności Konstytucji, "Ruch Prawniczy, Ekonomiczny i Socjologiczny" 2019, z. 3, s. 39-52.

Kusiak J., Rule of Law and Rules-lawyering: Legal Corruption and "Reprivatization Business" in Warsaw, "International Journal of Urban and Regional Research" 2019, vol. 43, iss. 3, s. 589-596.

Łukowiak D., Glosa do wyroku Trybunału Konstytucyjnego z 25 marca 2019 r., sygn. akt K 12/18 (wybór sędziów do składu Krajowej Rady Sądownictwa przez Sejm), "Przegląd Konstytucyjny" 2019, nr 3, s. 101-112.

Maciel G.G., Sousa de L., Legal Corruption and Dissatisfaction with Democracy in the European Union, "Social Indicators Research” 2018, vol. 140, iss. 2, s. 653-674.

Majchrowski J., Źródła prawa a praktyka polityczna, w: Źródła prawa. Teoria i praktyka, pod red. T. Giary, Warszawa 2016, s. 51-65.

Maksimiuk D., Z działalności Komisji KC PZPR do spraw Wymiaru Sprawiedliwości, Bezpieczeństwa i Porzadku Publicznego w 1957 r. Przyczynek do badań nad wpływem PZPR na wymiar sprawiedliwości, "Miscellanea Historico-Iuridica” 2015, t. 14 : 
Studia dedykowane Profesorowi Adamowi Lityńskiemu w 75-lecie urodzin i 50-lecie pracy naukowej, pod red. P. Fiedorczyka, s. 57-72.

Matczak M., Argumentum ad absurdum w uzasadnieniu decyzji stosowania prawa a założenie o racjonalności prawodawcy - analiza krytyczna, w: Uzasadnienia stosowania prawa, pod red. I. Rzucidło-Grochowskiej, M. Grochowskiego, Warszawa 2015, s. 102-115.

Mazur P., Uwagi o odpowiedzialności dyscyplinarnej sędziów za rażąca i oczywistą obrazę prawa w polskim systemie prawnym, "Ethics in Progress" 2017, t. 8, nr 2, s. 97-109.

Meandry prawa - teoria i praktyka. Ksiega jubileuszowa prof. zw. dra hab. Mieczystawa Goettela, pod red. E. Pływaczewskiego, J. Bryka, Szczytno 2017.

Minich D., Konstytucja - konstytucjonalizm - neokonstytucjonalizm, „Przegląd Prawa Publicznego" 2018, nr 12, s. 68-75.

Minich D., Konstytucja oraz konstytucjonalizm w dobie ponowoczesnej, w: Teoria prawa. Między nowoczesnościa a ponowoczesnościa, pod red. A. Samonek, Kraków 2013, s. 31-39.

Minich D., Veto players jako koncepcja rywalizacji o władze pomiędzy organami władzy państwowej, "Przegląd Prawa Publicznego” 2018, nr 7-8, s. 43-53.

Niezgódka-Medek M., Krajowa Rada Sądownictwa jako gwarant niezależności sądów i niezawisłości sędziów do czasu wprowadzenia zmian na przełomie 2017 i 2018 r., w: Konstytucja. Praworzadność. Władza Sądownicza. Aktualne problemy trzeciej władzy w Polsce, pod red. Ł. Bojarskiego, K. Gajewskiego, J. Kremera, G. Ott, W. Żurka, Warszawa 2019, s. 93-106.

Patora K., Analiza korupcji, „Studia Iuridica Toruniensia” 2018, nr 22, s. 253-270.

Peters A., Corruption as a Violation of International Human Rights, "European Journal of International Law" 2018, vol. 29, iss. 4, s. 1251-1287.

Pethe A., Tandel V., Gandhi S., Unravelling the Anatomy of Legal Corruption: Focusing on 'Honest Graft' by Politicians, "Economic and Political Weekly" 2012, vol. 47, no. 21, s. 55-62.

Pilipiec S., Zasada prawa do sądu w Konstytucji Rzeczypospolitej Polskiej i Konstytucji Federacji Rosyjskiej, "Annales Universitatis Mariae Curie Skłodowska, Lublin Polonia", Sectio G, 2003/2004, vol. 50/51, s. 151-165.

Piotrowski R., Pojeccia zastane w Konstytucji RP. Dylematy teorii i praktyki, w: Źródła prawa. Teoria i praktyka, pod red. T. Giary, Warszawa 2016, s. 21-50.

Piotrowski R., Sędziowie i granice władzy demokratycznej w świetle Konstytucji RP, "Ruch Prawniczy, Ekonomiczny i Socjologiczny" 2018, nr 1, s. 215-229.

Rakowska-Trela A., Krajowa Rada Sadownictwa po wejściu w życie nowelizacji z 8.12.2017 r. - organ nadal konstytucyjny czy pozakonstytucyjny?, w: Konstytucja. Praworzadność. Władza sądownicza. Aktualne problemy trzeciej władzy w Polsce, pod red. Ł. Bojarskiego, K. Gajewskiego, J. Kremera, G. Ott, W. Żurka, Warszawa 2019, s. 107-122.

Rakowska-Trela A., Sady i sędziowie wobec niedemokratycznych przemian, "Studia Politologiczne" 2018, t. 47, s. 299-315.

Siudowski M., Prawo do sadu. Raport z monitoringu ochrony praw podstawowych w Polsce, Lublin 2006.

Skrzypiński D., Odpowiedzialność sędziów w świetle zjawiska judykalizacji polityki, „Wrocławskie Studia Politologiczne" 2014, nr 17, s. 53-64. 
Skuczyński P., Bezpośrednie stosowanie Konstytucji RP przez sądy a odpowiedzialność dyscyplinarna sędziów, „Kwartalnik o Prawach Człowieka” 2017, nr 3-4, s. 88-95.

Skuczyński P., Nierepresyjne funkcje odpowiedzialności dyscyplinarnej a model postępowania w sprawach dyscyplinarnych, "Przegląd Legislacyjny” 2017, nr 3, s. 35-53.

Taborowski M., Mechanizmy ochrony praworządności państw członkowskich w prawie Unii Europejskiej. Studium przebudzenia systemu ponadnarodowego, Warszawa 2019.

Tkaczyk E., Konstytucyjne prawo do sądu jako jedna z najważniejszych gwarancji praw człowieka w państwie demokratycznym. Aspekt teoretyczny, "Studia Prawnicze i Administracyjne" 2017, nr 20(2), s. 39-46.

Tomza A., Kwestia politycznych nominacji sędziów do Sądu Najwyższego Stanów Zjednoczonych w pogladach Antonina G. Scalii - In memoriam, „Folia Iuridica Universitatis Wratislaviensis" 2018, vol. 7, no. 1, s. 161-172.

Tuleja P., Division of Power and the Problem of Excessive Concentration of Power in the Light of the Polish Constitution, „Przegląd Konstytucyjny” 2018, nr 4, s. 59-75.

Tworzenie a stosowanie prawa w Polsce. Teoria i praktyka, pod red. M. Mazuryka, D. Kotłowskiego, K. Sadowskiego, Warszawa 2014.

Utz A.F., Pojęcie prawa w teorii i praktyce, "Roczniki Nauk Prawnych" 2010, nr 2, s. 7-15.

Walczak W., Korupcja jako sieć wpływów, powiązań i zależności, „Przegląd Bezpieczeństwa Wewnętrznego" 2018, nr 19, s. 11-41.

Walczak W., Korupcja-ujęcie prakseologiczne i ekonomiczne, „Policja. Kwartalnik Kadry Kierowniczej Policji" 2019, nr 2, s. 10-21.

Walczak W., Legalna korupcja metodą zapewniania korzyści majątkowych i osobistych, „Annales Universitatis Paedagogicae Cracoviensis. Studia de Securitate” 2020, nr 1, s. 217-256.

Walczak W., Nadużycie władzy publicznej elementem korupcji - próba szerszego ujęcia zjawiska, „Kontrola Państwowa” 2019, nr 3, s. 109-125.

Walczak W., Przestępstwa korupcyjne a legalna korupcja - aspekty ekonomiczne i prawne, "Przegląd Bezpieczeństwa Wewnętrznego" 2019, nr 21, s. 44-81.

Wielki R., Dostęp do informacji publicznej jako prawne narzędzie zwalczania korupcji. (Glosa do wyroku Naczelnego Sadu Administracyjnego z dnia 3 stycznia 2012 r., sygn. akt: I OSK 2157/11), "Opolskie Studia Administracyjno-Prawne" 2017, nr 3, s. 115-123.

Zajadło J., Magiczny trójkąt: prawodawcy, sędziowie, profesorowie, w: Konstytucja. Praworządność. Władza sądownicza. Aktualne problemy trzeciej władzy w Polsce, pod red. Ł. Bojarskiego, K. Gajewskiego, J. Kremera, G. Ott, W. Żurka, Warszawa 2019, s. 65-90.

Zalizowski G., Prawo do sądu na tle Konstytucji Rzeczypospolitej Polskiej w kontekście europejskiej Konwencji o ochronie praw człowieka i podstawowych wolności, w: Duch praw w krajach Europy Środkowo-Wschodniej, pod red. M. Kępy, M. Marszała, Wrocław 2016, s. 13-31. 